\title{
World-Systems Analysis and Archaeology: Continuing the Dialogue
}

\author{
Thomas D. Hall • P. Nick Kardulias • \\ Christopher Chase-Dunn
}

Published online: 17 December 2010

(C) The Author(s) 2010. This article is published with open access at Springerlink.com

\begin{abstract}
Many archaeologists have used world-systems analysis in precapitalist settings. Some have criticized it; others have dismissed it out of hand. Critiques include that it was developed for the "modern" world, that it is overly economistic, that it neglects individual actors, and that it inappropriately uses modern analyses in ancient settings. Although there is some validity to these charges when applied to Wallerstein's original formulation, most are misdirected. The critiques are rooted in inattention to the last three decades of work on world-systems, especially modifications made with the explicit intention to make world-systems analysis useful in precapitalist settings. Newer comparative versions of world-systems analysis were initially developed to better understand the evolution of world-systems that gave rise to the modern world-system. These new advances are useful for the study of interregional interactions and long-term development. Archaeologists are well placed to contribute to the further development of world-systems analysis; they can shed light on ancient world-systemic processes and the origins of the modern worldsystem, provide empirical backing for hypotheses, and raise new theoretical and empirical questions.
\end{abstract}

T. D. Hall ( $\bowtie)$

DePauw University, 523 The Parkway, Ithaca, NY 14850-2277, USA

e-mail: thall@depauw.edu

P. Nick Kardulias

Department of Sociology and Anthropology, College of Wooster, Wooster, OH 44691, USA

e-mail: pkardulias@wooster.edu

C. Chase-Dunn

Institute for Research on World-Systems, University of California, Riverside, CA 92521-0419, USA

e-mail: Christopher.Chase-Dunn@ucr.edu 
Keywords World-systems analysis - World-systems theory · Intersocietal interaction - Sociocultural evolution · Social change · Incorporation · Negotiated peripherality

Historical sociology is ... the attempt to understand the relationship of personal activity and experience on the one hand and social organization on the other as something that is continuously constructed in time. It makes the continuous process of construction the focal concern of social analysis. That process may be studied in many different contexts ... The particular context to which sociologists have chosen to pay the most attention is the one I have called the transition to industrialism. But in the end historical sociology is more a matter of how one interprets the world than of what bit of it one chooses to study. (Abrams 1982, pp. 16-17)

... by comparing our modern society with earlier civilizations, we may see more clearly the likely results of trends such as the destruction of tropical rainforests and the rapid shrinking of the farming population in the United States. The "lessons of history" cannot necessarily tell us exactly what tack to follow today, but they can teach us what courses of action have succeeded or failed in the past and why. (Sabloff 1990, p. 169)

\section{Introduction}

Archaeologists have long recognized that interactions with areas and peoples outside the immediate zone of excavation are often vital to understanding local events (Hall and Chase-Dunn 1993; Kardulias and Hall 2008). Diffusion is an old topic in archaeology. More important are impositions of new relations from the outside; even more neglected, but perhaps more significant, are changes that derive from local efforts to resist or negotiate with outside forces and actors and the impacts of these local changes on the outside world. In short, even the smallest ethnographic or archaeological site cannot be understood only in isolation. The converse is also the case: no local site can be understood only from an external perspective. Rather, the interaction of the two must be examined.

In 1993 Hall and Chase-Dunn reviewed developments over the previous two decades since Wallerstein (1974) published volume one of the Modern WorldSystem. They discussed a number of theories and theorists who seemed compatible with world-system approaches (Hall and Chase-Dunn 1993, pp. 131-132) and included a separate bibliography of such works (pp. 137-143). Work on worldsystems analysis and archaeology has continued to grow significantly in the last two decades in virtually all the social sciences. This article surveys some of that new work and builds on the earlier summary. To minimize repetition and to conserve space, we do not recapitulate the 1993 article here. In 2008 Kardulias and Hall 
published a brief article addressing a few of these same topics. Galaty (2011) recently made an elegant and persuasive argument for use of world-systems analysis in archaeology. We recommend these articles to readers just now entering this dialogue.

Our primary goal in this article — and its partial literature review-is to further that dialogue. We argue that archaeological theorizing and world-systems analysis have much to learn from each other. Not the least of these lessons is to use the theoretical and especially the empirical progress in both to critique and extend the other. Furthermore, methods of world-systems analysis also have developed significantly. Many of these developments are cogently reviewed and illustrated in a recent issue of Journal of World-Systems Research devoted to "Methodological issues in macro comparative research" (Byrd and Smythe 2010). Our goal is not to turn archaeologists into world-systems analysts but to provide a modicum of guidance to this large and often contentious literature, and to point out ways in which that literature may be of use in addressing archaeological issues. Conversely, we hope that archaeologists who are working on issues germane to world-systems analysis (WSA), especially the evolution of world-systems, will use their research to contribute to that work.

We begin with a brief summary of the early forms of WSA, with an aside on how we see the differences between theories and other approaches to theoretical bodies of literature. We then summarize more current WSA, noting several missed opportunities in the dialogue between WSA and archaeology. We finish with extended critiques and descriptions of the use of WSA in archaeology, and an invitation to join the dialogue.

\section{World-systems theory and world-systems analysis: A brief recapitulation}

We begin with a recapitulation of Wallerstein's original formulation, then discuss some of the modifications and illustrate our argument with a few brief examples. Along the way we indicate literature in which readers interested in pursuing the arguments can find much more detailed examples.

World-systems theory (WST) developed initially in the 1960s and 1970s as a response to the prevailing functionalist theories in the social sciences (Shannon 1996). Wallerstein (1974) began his analysis of a tripartite division of the capitalist societal system with the exploitative expansion of European states in the "long 16th century" (1450-1640). Recently, Wallerstein (2004, p. 11) noted that several key trends in the 25-year period between 1945 and 1970 laid the foundation of WSA:

The concept of core-periphery developed by the United Nations Economic commission for Latin America (ECLA) and the subsequent elaboration of "dependency theory"; the utility of Marx's concept of the "Asiatic mode of production," a debate that took place among communist scholars; the discussion among historians of western Europe about the "transition from feudalism to capitalism"; the debate about "total history" and the triumph of the Annales school of historiography in France and then in many other parts of the world. 
Of particular importance is the core-periphery concept. Among the first to confront this issue was Frank (1966), who described a scheme in which there are metropoles (capitalist nations) that siphon raw resources from satellites (Third World nations), "underdeveloping" them. Within underdeveloped states, there are metropoles, such as ports and urban areas that in turn extract from their own satellites (villages). Frank referred to this far-reaching exploitative process as the development of underdevelopment because metropoles systematically depleted the resources of satellites, in layers of exploitation (Frank 1966, 1967). Wallerstein called metropoles cores and satellites peripheries. Semiperipheries are metropoles in underdeveloped nations that exploit resources of their satellites, while they in turn fall prey to exploitation by the Western core.

Wallerstein and Frank sought to explain the rise of capitalism. For Wallerstein the key features and processes are world-systemic, "defined by the fact that their self-containment as an economic-material entity is based on extensive division of labor and that they contain within them a multiplicity of cultures" (Wallerstein 1974, p. 348). More recently he explains further that a world-system is "a spatial/ temporal zone which cuts across many political and cultural units, one that represents an integrated zone of activity and institutions which obey certain systemic rules" (Wallerstein 2004, p. 17). He uses the term "world" to refer to interacting politico-economic units and not the entire planet. This is why Wallerstein insisted that the term world-system be hyphenated. We follow his usage. A world-system is not a system of planetary size. Rather the term refers to a self-contained unit. We conceive of world-systems as objects that combine two essences, worldness and systemness, in a single unit. Scholars who do not follow this conception do not use the hyphen. Throughout this article we use the hyphen when world-system is used in our convention. Otherwise we omit the hyphen. This is an old debate (see Thompson 1983; Wallerstein 1983).

Furthermore, he distinguishes between world-empires and world-economies. In the former there is a single political structure over a vast area. A world-economy requires the presence of core states and peripheral areas. Core states possess complex political structures (stratified class systems with large bureaucracies) and, by means of superior technology, exercise control over the major facilities of production, transportation, and communication. Political organization in peripheral areas is at the pre-state or incipient state level and is usually relatively weak compared to that in core states. Core states incorporate peripheral areas into the capitalist world-economy because they often contain important resources. Core states exploit the labor and material resources of peripheral areas and receive a disproportionately large share of the surplus or benefits. European states competed among themselves for access to peripheral areas through colonization to increase profits. Interposed between cores and peripheries are semiperipheries that often act as intermediaries between the two extremes of the system. Over the past three and a half decades, various scholars have significantly augmented the original worldsystems formulation to address a series of questions.

Others have criticized WST for being too economistic, ignoring individual actors, and for using or importing modern analyses inappropriately into ancient settings (see Hall 1989, Ch. 10 for a summary). There is some validity to these charges, but 
they are largely misdirected. Often the critics correctly observe that WST writers had not addressed these issues, but they err in claiming that it was impossible to address them with WST. Hall's (1989) study of the American Southwest addressed some of these criticisms, especially emphasizing the roles of peripheral residents in shaping incorporation processes. Others have conducted similar studies (for detailed reviews see Hall 2000a, b, 2002a).

While Wallerstein $(1993,1995)$ explicitly limited his model to the past five centuries, many archaeologists and historians initially thought it might be useful to understand and examine the overlapping interactions of peoples in antiquity (summarized in Hall and Chase-Dunn 1993). The modifications to WST represent analogous refinements and elaborations. Thus, world-systems analysis has replaced world-systems theory (note the plural). WSA expands the temporal range of studies, introduces comparative analyses, and typically transforms assumptions in the early formulations of WST into empirical questions. In short, WSA is a general approach that encompasses several competing theories, all of which emphasize interaction as central to cultural and social change (Denemark et al. 2000 provide cogent summaries, especially the chapters by Denemark [2000, pp. 299-312] and Thompson [2000, pp. 287-298]). We also note that the original impetus for extension of WSA into ancient and prehistoric settings was, and to some extent remains, to understand how and why the modern world-system appeared when and where it did, in the form it did, and how it might change in the future (see Beaujard 2010; Beaujard et al. 2009; Chase-Dunn and Babones 2006; Chase-Dunn and Hall 1997, 2009; Chew 2008; Hall and Chase-Dunn 1994, 2006; Sabloff 1990). But like much of archaeology, it has become focused on long-term change or evolution of world-systems and the societies that constitute them.

Reaction by archaeologists to the initial formulation of WST began quickly (Blanton and Feinman 1984; Pailes and Whitecotton 1975, 1979). Later, Feinman (1999) noted the need to consider conditions at different scales if one is to apply the theory in any meaningful manner. A number of other archaeologists used WST and/ or related concepts in research on Latin America (Alexander 1999; Kepecs and Kohl 2003; La Lone 1994, 1999, 2000; Schortman and Urban 1992, 1994, 1999). O'Brien (1994), Peregrine (1992), and Peregrine and Feinman (1996) used WST to discuss developments in prehistoric North America. Sherratt (1993, 1997, 2003, 2006), Susan Sherratt (2001, 2003; see also Sherratt and Sherratt 1991, 1993), and Kristiansen (1998a, b; Kristiansen and Larsson 2005) have studied various aspects of prehistory through a WST lens.

We argue that these modifications to the initial formulation of WST do not demonstrate weaknesses. Rather they are an integral part of theory testing and theory building. As an analogy, other major theories have been altered without being discarded. For example, Darwin's approach to evolution identified a vital mechanism, natural selection. Yet he was mistaken about the transmission of physical traits between generations. Many biologists have modified Darwin's formulation (Jablonka and Lamb 2005). Gould and Eldredge (2000) challenged Darwinian gradualism with a punctuated equilibrium model. Nonetheless, evolutionary biology is still solidly embedded in Darwin's views. 
We argue that employing generalization provides useful insights, but that we should do so while retaining an understanding of individual action. This, of course, parallels the distinction between general and specific evolution raised by Sahlins and Service (1960; Sahlins 1960). Some critics argue that WST obscures the latter through its emphasis on large-scale processes and a formulaic application of the core-periphery-semiperiphery triad. We address this issue through a focus on what happens at peripheries as a process of negotiation, noting that this is rarely a onesided imposition. For example, Portuguese merchants had to work out the nature of their status as traders with local leaders and elites in the India trade in the 15th and 16th centuries, and Native Americans maneuvered to get more or better products in the fur trade (Kardulias 1990, 2007).

\section{Theories, perspectives, schools of thought, and "paradigms": An excursus}

At different times, WSA has been described as a school of thought, a perspective, a theory, and a paradigm. We begin by reviewing the distinctions among these concepts. A theory is an explanation built on a series of logical assumptions and empirical evidence. Theories are dynamic. They change through time as they are revised in light of new findings and repeated testing. While it is possible to disprove a theory, it is impossible to prove one. This is especially the case under the conditions encountered by archaeologists and historians of ancient societies, because it is always possible that new evidence will be "unearthed." This new evidence may point to extensive revisions or development of a new theory. That new theory, however, needs to be able to explain all that the old theory explained and the new discovery. Thus, theory building and theory testing are part of a spiraling process that builds generalizations from empirical data. Those generalizations lead to logical explanations, which in turn must be operationalized and then tested further with new empirical evidence (see inter alia Abrams 1982; Wallace 1971).

In contrast, a perspective implies one general approach to an array of problems. It recognizes and accepts, at least implicitly, that there are other perspectives on the same array of problems. Typically, a perspective does not seek to explain everything about an array of problems. Rather it examines only some aspects. Hence, it is sometimes used as a synonym for discipline or a school of thought. By the late 1980s and into the 1990s, "perspective" began to replace "theory" as a descriptive label for world-systems thinking (e.g., Peregrine 1992; Shannon 1989, 1996). This was an effort to underscore that world-systems thinking was not a monolithic theory but a collection of approaches that share key aspects of the early versions. Namely, they are forms of human organization that are larger than societies or states, and there is a dialectic between the world-system and its constituent parts. Each shaped the other.

A school of thought is a group of scholars who are investigating broadly similar processes and events with a variety of approaches. Some of these approaches are contradictory, but they share a wide set of methods and assumptions. Schools of thought examine data from a shared, but general perspective. Our argument is that 
WSA should be included in the spectrum of perspectives used to investigate and explain archaeological data.

In contrast, a paradigm is a model for asking questions. These are not random questions but derive from a more-or-less coherent body of assumptions and empirical facts. When those questions are answered, the new information improves understanding of the relevant processes. Furthermore, those results are inserted back into the paradigm to amend and modify it to generate more questions. When a paradigm no longer produces interesting questions or fails to address them adequately, it falls out of use. Scholars often examine unexplained and unexplainable "anomalies" for clues to develop a new paradigm. When a new paradigm begins to replace an older one, there has been a paradigm shift. Unfortunately "paradigm shift" has become a synonym for any intellectual change. Here we draw on Kuhn's $(1970,1977)$ concept of paradigm metaphorically but do not follow his argument completely. A key point is that a paradigm encompasses many different theories that differ in details; they are often contradictory yet share some basic assumptions.

These brief definitions show considerable overlap. A key point is that while theories can be proven wrong, but schools of thought, paradigms, or perspectives cannot. They are more, or less, useful for understanding the problems at hand. Furthermore, they are subject to modification based on new empirical evidence without vitiating the paradigm entirely. Our key argument, then, is that worldsystems analysis remains useful in prompting the kinds of questions that when answered lead to new understandings, especially of intersocietal interaction patterns. This is, we argue, what Abrams (1982) and Sabloff (1990) suggest in the epigraphs at the beginning of this article.

To elaborate, we view macroanalysis as a school of thought or a perspective. As noted above, there are many other approaches to long-term social change, especially before AD 1500 (for extended reviews see Denemark 2000; Hall 2000a; Sanderson 1995; Thompson 2000). A number of edited volumes explore different approaches (Beaujard et al. 2009; Denemark et al. 2000; Hornborg and Crumley 2007; Hornborg et al. 2007; Kardulias 1999c; Parkinson and Galaty 2010). Other scholars have added works of value. Many archaeologists have addressed the issues of social evolution (Marcus 2008) and collapse (e.g., McAnany and Yoffee 2010). Lenski (1966, 1976, 2005) has long been an advocate of a long-term approach to sociology, as has Sanderson (1999a, b, 2001). Turchin (2003, 2009; Turchin and Nefedov 2009) has added mathematical models. Wilkinson (2000) has discussed the expansion of central civilization. Many world historians (Burke and Pomeranz 2009; Christian 2004; Diamond 1997, 2005; McNeill 1963, 1964, 1995; McNeill and McNeill 2003) also address these issues.

We consider world-systems analysis a paradigm. The use of the plural systems indicates that there have been many types of world-systems, not just the contemporary one. Finally, in addition to all the different descriptors attached to the term "world-system," we note that we follow Wallerstein's original intent that the "world" in "world-system" refers to a more-or-less self-contained unit, not the planet Earth. Two caveats are in order here. First, as WSA has concentrated more and more on networks, the idea of precise boundaries has become less and less 
useful (for discussions of networks see Bunker and Ciccantell 2005; Castells 2009, 2010a, b; McNeill 2000; Smith and Timberlake 2001; and other articles in the same issue of American Behavioral Scientist).

White and his collaborators have been developing sophisticated ways of analyzing networks and linking networks to the study of complexity. Although not explicitly focused on WSA, the discussions of networks could be applied fruitfully to the study of world-system networks and possibly to archaeological settings (White 2003a, b; White and Johansen 2005).

Still, a world-system is bounded by sharp falloffs in its various networks, many of which may not coincide. Second, by the late 20th century the "modern worldsystem" had indeed become planetary. The planetary nature of the modern worldsystem is often what many writers mean by globalization (see Chase-Dunn 2006; Hall and Chase-Dunn 2006; Kristiansen 1998b; Pitts 2008; Rowlands 1998; S. Sherratt 2003; Sklair 2006).

\section{World-systems analysis: A brief summary}

WSA covers a broad range of issues and topics, but here we concentrate on basic definitions and some problems, and suggest changes to accommodate the work of archaeologists, especially in terms of core-periphery relations and the processes of incorporation. WSA shares with other accounts of intersocietal interactions a basic tenet that past cultures did not exist in pristine isolation. Rather contacts, direct and/ or indirect, affected groups involved in large networks. Where WSA differs from other interaction models is in the geographic extent studied, a stress on the hierarchical aspects of systems, and, for some, the desire to outline long-term cycles of expansion and contraction in system structure and intensity (Chase-Dunn and Anderson 2005).

One question then is what exactly does WSA advocate? We focus on what scholars say now, not only what Wallerstein said in 1974. WSA suggests that (1) societies do not now nor at any time in the past exist in splendid isolation, and (2) societal trends follow cycles or patterns. This search for regularities in the archaeological record does not mean that we ignore idiosyncrasies. In fact, WSA forces us to see the forest of external links in which individual sites are embedded. It is akin to the important role that survey archaeology plays in understanding regions or landscapes of interaction. WSA is an approach that provides a conceptual framework to comprehend how systems operate.

\section{Criticisms and revisions}

Quite early Schneider (1977) objected that preciosities formed an important part of the trade between cores and peripheries, whereas Wallerstein focused on bulk goods. Wallerstein treated incorporation into a world-economy as one-sided. Hall argued that one must study local conditions in peripheral areas as well as the capitalist economy in core states to understand fully the nature of incorporation. Hall (1986, 1989) noted that incorporation into a world-economy is a matter of 
degree and that nonstate peripheral societies play a more active role in resisting and shaping incorporation than generally argued. This effect was particularly strong in antiquity when complete domination of a peripheral zone was technologically and politically impossible. Thus, incorporation was less encompassing in antiquity. Chase-Dunn and Hall (1997, Ch. 4, especially Fig. 4.4, p. 63) suggest that there is a continuum of incorporation with attendant effects on the societies involved. Others note that people on the periphery can at times negotiate effectively because they control access to a key resource.

A major issue for archaeologists is the degree to which WSA applies to antiquity. Archaeologists have used the approach in Mesoamerica (Berdan and Smith 2003a, b; Blanton and Feinman 1984; Pailes and Whitecotton 1979; Santley and Alexander 1992; Smith and Berdan 2003a), the American Midwest (Peregrine 1992; Peregrine and Feinman 1996), and other regions. For the Old World, Kohl (1989) modified WSA to fit ancient conditions. In a critique of the primitivist views of Finley and others, Kohl cites many examples of price fixing, inflation, and market mentality that demonstrate the complexity of ancient economies. He builds a strong argument for the existence of an intricate multicentered world-system during the Bronze Age in Southwest Asia. Unlike many modern technologies, ancient ones were often portable and could be moved easily from core to periphery. This fact, along with the lack of major colonization, made it possible for peripheries to retain their autonomy and precluded much of the exploitation and underdevelopment characteristic of the modern world-system. Kohl argued that the "barbarian" peripheries had a significant impact on how core regions developed. See Beckwith (2009a), especially the Epilogue (Beckwith 2009b, pp. 320-362), for an elaborate discussion of the term barbarian, especially as used and applied to central Eurasia. Kohl (2004) has stated recently that there was a dramatic increase in tin bronzes in Transcaucasia between the Early and Late Bronze Age, which suggests the region had access to substantial amounts of tin from several sources, some of which may have been in Afghanistan.

Frank (1993) argued that areas on the margins of the Near East, while important as regions of economic interaction, were subject to the influences of the "super powers" of the time: Egypt, Assyria, the Hittites, and other states in Mesopotamia. Frank contended that an Afroeurasian world system has existed for 5,000 years, since the origins of the state. Frank listed five theoretical premises: (1) the seminal importance of long-distance trade relations; (2) the accumulation of capital ("cumulation of accumulation") drives history; (3) core-periphery structure is a key trait; (4) shifting hegemony and rivalry characterize the world system; and (5) economic development of the system occurs in long cycles of alternating ascending and descending phases.

Schortman and Urban $(1987,1992)$ found world-systems terminology limiting and prefer to place discussion at the level of interregional interaction, while they still use the core-periphery concept. They suggest that the units of study should be society and ethnicity, which are connected by the flow of information. Their archaeological work in Mesoamerica stresses the role of elites who used regional interaction to generate and sustain their elevated status (Schortman and Urban 1994, 1999). 
Chase-Dunn and Hall (1997) go further and argue that change occurs not only within individual societies but in entire world-systems. They seek to provide a comparative matrix within which to study contacts for all societies, even stateless foraging groups. While Frank and Gills (1993) argue that an Afroeurasian world system came into existence in the Bronze Age, Chase-Dunn and Hall (1997) suggest such connections were in place in the Neolithic. Of special relevance for archaeology is Chase-Dunn and Hall's (1997) definition of two kinds of coreperiphery relationships: (1) core-periphery differentiation, which involves groups of varying sociopolitical complexity that engage in active interchange, and (2) coreperiphery hierarchy, which refers to a situation in which one or more groups dominates other groups in the system. They argue that this distinction is necessary because exploitation does not necessarily characterize all interactions between cores and peripheries. In short, they transformed Wallerstein's assumption that cores always exploit peripheries into an empirical and theoretical issue. The issue is when and how core-periphery differentiation, which is quite common in precapitalist settings, becomes core-periphery hierarchy, which is somewhat less common in earlier periods. Archaeologists could draw on a wide variety of empirical examples to develop theoretical accounts for this transformation, or its lack.

In another innovation, Chase-Dunn and Hall (1997) argue that world-systems typically have four sets of boundaries, marked by sharp falloffs in density of exchange of bulk goods, political and military interactions, luxury or prestige goods exchanges, and information exchanges. These include a system of exchange of lowvalue-to-weight goods, which they label a bulk goods network; a system of regularized military or political interactions, which they label a political-military network; a system of more or less regular exchanges of high-value-to-weight goods, which they label a prestige or luxury goods network; and a system of information of all kinds, factual and/or cultural, which they label an information network. When drawn as sharp lines in diagrams (e.g., Chase-Dunn and Hall 1997, p. 54, Fig. 3.1), the networks give a false sense of precision. Rather they should be imagined as a contour map where the isoclines of the density of exchanges are bunched together. Such sharp falloffs, or cliffs, would be the "boundary" of a network. They are frontiers internal to a world-system (Hall 2009). To form a boundary, exchange must be systemic, even if inchoate. Whether a specific good is a bulk or luxury item is not solely a property of the good itself. Rather it is a consequence of transportation costs and the productive uses of that item in both the sending and receiving economies.

The boundaries between core areas, peripheral areas, and semiperipheral areas are similarly fuzzy and gradual. In particular, the relationship between peripheries and cores is central to WSA. In discussing tribal boundaries Parkinson (2002b, p. 8, see also Parkinson 2006) notes, "The tendency of different segments within the system to constantly renegotiate their relationship with each other can preclude the formation of established social boundaries over the long term, usually resulting in a complicated archaeological picture with fuzzy lines approximating the borders between different prehistoric 'groups.' "We would extend Parkinson's comment to include all world-system boundaries - within and between core, semiperiphery, and periphery - and along the edges of the bulk goods network, the political-military 
network, the prestige goods network, and the information network. Parkinson's efforts to delimit tribal areas archaeologically are a useful starting point to delimit other boundaries and/or transition zones.

Allen (1997) contributes the useful concept of contested periphery, which refers to a region with certain key resources or in a strategic location that lies between major states and is a prize over which the latter contend. The competition over the contested region may be economic or it could involve military action (see Cline 2000 concerning the Jezreel Valley in the Levant). Cline (2000) suggests that the Troad was a contested periphery, "a zone of cross-fertilization for the ideas, technology, and material goods which came into and crossed through the region." We would add that peripheries can be zones of innovation. Peripheries, especially when contested, can be key areas for economic, political, social, and religious competition and exchange, but their status often is tenuous if they are the locations where competing empires clash. Again, this is an issue where archaeologists could shed a great deal of empirical light. Conversely, the concept and the underlying relations of a contested periphery could help make sense of regions that remain nearly autonomous from surrounding states or world-systems.

Stein $(1999,2002,2005)$ has offered important critiques of WSA applications in archaeology. He identifies three key assumptions that underlie WSA: centralized control by the core, core regulation of unequal exchange in its favor, and longdistance trade determines the character of the economy in the periphery. He then notes instances in which these relations do not hold. While true for Wallerstein's initial formulation, Stein uses a broad brush to dismiss the various revisions, which he suggests dilute the approach to an extent that is untenable. Stein argues that efforts to use WSA demonstrate its deficiencies. While he is correct that the archaeological record often confounds Wallerstein's basic assumptions, he does not acknowledge Chase-Dunn and Hall's distinction between core-periphery differentiation and hierarchy, or their focus on the roles of people in the periphery as active agents of change.

Stein makes a case for the utility of trade-diaspora and distance-parity models as alternatives that are sensitive to both the general and historically/culturally specific events that structure interaction. In a trade diaspora (Curtin 1984), tightly organized foreign merchants engage in substantial commercial activities with a host community but associate with others who share the same cultural identity. Stein demonstrates that such communities fall along a continuum, from minor players who are tolerated by their hosts to powerful groups that dominate the indigenous population. Using the distance-parity model, Stein suggests that the ability of the core to exercise its will (i.e., power) over its periphery declines as distance from the core increases. Stein examines the emergence of civilization in southern Mesopotamia and the Uruk expansion (3700-3100 BC), during which Mesopotamian colonies were established in the Zagros region and the upper reaches of the TigrisEuphrates drainage. He argues that southern Mesopotamians settled along wellknown routes and that their relations with local polities varied. He then describes various Late Chalcolithic polities of southeast Anatolia that exhibit craft specialization, monumental public architecture, and administrative artifacts (stamp seals and sealings). 
Stein also disputes Algaze's (1993a, b, 2008) claims for an Uruk world system. He suggests that Uruk colonists in southern Anatolia had minimal influence on the local residents. This is as one would expect since the outsiders were a distinct minority a great distance from their homeland. He implies that the colonists were at the site only at the sufferance of the locals, who selectively adopted only those foreign elements they found particularly useful. This assessment rings true. Kardulias (2007) found evidence for similar actions by local people confronted by intruders in the North American fur trade and in ancient Cyprus.

We appreciate Stein's demonstration that people on the periphery can negotiate the terms of their involvement in exchange networks. However, we disagree with his assessment of WSA. While his criticisms of Wallerstein have merit, Stein does not attend to the array of modifications that WSA now comprises. We would go further and argue that what he is describing are actually alternative forms of early world-systems that eventually merged to be larger systems. Indeed, his analysis could readily be recast in world-system terms. Here is a missed opportunity to assess how and why initially variant forms eventually condensed to only a few forms. This, of course, is social evolution at work in many situations: initial variety and diversity of a new form of social organization that over time condenses into only a few, or even one, form. By ignoring these issues, he constructs what appears to be a "tighter" explanation of localized conditions but vitiates the possibility of asking how this changed into different forms.

\section{Missed opportunities}

As reviewers, we have been frequently frustrated by archaeological empirical research and analyses that could make significant contributions to various debates, hypotheses, and macroanalyses, especially world-systems analysis, but fail to do so. These missed opportunities could have contributed to wider intellectual discourses and understandings that would both benefit those other conversations about macro processes and demonstrate that new archaeological discoveries and discussions are germane to far more than the "small circle of friends" who typically discuss them.

A key reason for missed opportunities is that many of the relevant writings are rooted in disciplines other than archaeology and appear in venues not usually perused by most archaeologists. Much of the work is in various world-systems outlets such as the Journal of World-Systems Research, the Political Economy of the World-System annuals (see http://www2.asanet.org/sectionpews/pewspubshp.html for a general list; Chase-Dunn and Anderson [2005]; Friedman and Chase-Dunn [2005]; Goldfrank et al. [1999] are especially germane to topics discussed here). Much more has appeared in historical works, especially in world history (e.g., Journal of World History) and what is now known as "big history," which traces history from the big bang forward, such as Christian's (2004) Maps of Time. Other sources include writings about social change (e.g., Sanderson 1995, 1999a, b, 2001; Sanderson and Alderson 2005) and proceedings of two conferences held at the University of Lund, Sweden, in 1995 and 2003 (Denemark et al. 2000; Hornborg and Crumley 2007; Hornborg et al. 2007). These problems are further complicated 
because many writings are directed to empirical and/or theoretical issues that are not couched in terms used in archaeological discourse, yet they do discuss issues that might be of interest to archaeologists.

Another issue is the continuing debate in archaeology and anthropology about the value of generalizing approaches (see Kohl 2008, also Hegmon 2003, 2005; Watkins 2003). The argument is about the fundamental nature of explanation as either bottom-up or top-down. While this is in many ways a caricature of a complex issue, it gets at a fundamental-perhaps the basic_-divide in the discipline between those who support a scientific approach and those who espouse a perspective that privileges individual, unique developments. Each camp can be identified by a host of key terms or buzzwords. Code words or indicators of the generalizing approach include processual, problem-oriented, systematic, positivist, normative, general laws, scientific, search for patterns, and others. The other approach has its array of verbal markers: postprocessual, particularistic, agency, interpretive, hermeneutic, cultural construction, and deconstruction, among others.

Our position is that both sides are complementary contributions to studies of the past. We focus on the debates that center on sociocultural evolution and absorption of nonstate peoples into state systems (on archaeology and culture change see BellFailkoff 2000; Burmeister 2000; Tsetskhladze 2003; on WSA and migration see Hall and Kardulias 2010; Jones and Mielants 2010; Kardulias and Hall 2007). Many archaeologists are familiar with the basic elements of world-system theory as developed by Wallerstein (1974) but lack familiarity with recent developments, and even developments reviewed in the Hall and Chase-Dunn 1993 article. Wallerstein (2004) and Chase-Dunn and Babones (2006) summarize many of these developments. Finally, much WSA is in extensive monographic studies, which in fact do address these issues and many other relevant matters, but whose substantive content is often of little interest to archaeologists (e.g., Hall 1989, 2000b, 2002a).

Most frustrating has been the task of reviewing articles or books that make a passing nod to "world-systems theory," citing Wallerstein's 1974 volume as if nothing had been written since then or only noting the volume by Frank and Gills (1993). Besides the obvious pique at skipping over much of our own writings, and the equally obvious point that some archaeologists have made major contributions, it creates a puzzle about why this happens among otherwise careful and diligent scholars (Kardulias 1999c). One problem is that in submitting articles that are largely descriptive, authors are prodded to put their findings in some theoretical context. If the finding entails some evidence on intersocietal interaction, then world-systems theory is used as a handy foil. But that use both misunderstands the cycles of theory building and theory testing and entirely misses the nature of world-systems analysis. Claiming that Wallerstein's original formulation does not apply to archaeological problems is both a statement of the obvious and a clear demonstration that the author has not read or understood any of the arguments and evidence presented in the last 36 years. We do not object to "site reports" or descriptive papers; what we do object to is citing Wallerstein (1974) as a straw man.

Another reason why some reject WSA might be a presumed faddishness of scholarly traditions based on an assumption that WSA is now passé. This, in turn, 
would seem to have roots in the widespread critique that world-systems analysis as presented by Wallerstein in 1974 was not written for the kinds of contexts that archaeologists typically investigate. This is definitely the case, but to restate this at the end of the first decade of the 21st century is, at its kindest, to belabor the obvious. Indeed, in 1993 Wallerstein himself questioned such applications of his analyses, in spite of the attempt by Frank and Gills to do so in the same book that contained Wallerstein's essay. At a minimum Wallerstein's recent Introduction to World-Systems Analysis (Wallerstein 2004) should be consulted. Especially salient is his annotated bibliography, which indicates that he has become somewhat more receptive to the extension of his ideas to times before the rise of the modern worldsystem, c. AD 1500. As we have noted, some other scholars find WSA a convenient straw man to bolster some other approach. In doing so, they throw out the baby with the bath water. We do not argue that WSA is the only useful approach to issues of intersocietal interaction; we argue that it remains useful along with other approaches noted above. This is not an either/or situation; it is a both/and situation.

Several edited volumes have explored various dimensions of WSA since 1993. Sanderson's book (1995) developed from discussions at meetings of the International Society for the Comparative Study of Civilizations in 1993. This relatively small organization focuses on "civilizations," approximately in the sense used by Toynbee and other early world historians. Papers compare and contrast WSA approaches with various civilizationalist approaches. Several of the chapters were written by archaeologists.

Kardulias's volume (1999c) grew out of a series of panels at the Central States Anthropological Society and at the American Anthropological Association in 1995. The opening and closing chapters (Hall 1999; Kardulias 1999b) provide summaries of the state of the discourse at the end of the 20th century. Hall's summary emphasizes that WSA needs to be applied bottom-up as well as top-down, though at that time most of the literature followed the latter approach. La Lone (1999), in the penultimate chapter, provides an ethnographer's assessment of the utility of WSA. Kardulias summarizes the volume in the final chapter. In between are 11 chapters by archaeologists who test various world-system hypotheses. Modelski and Thompson (1999) summarize work in political science, and Frank (1999) discusses the benefits and pitfalls of using WSA in archaeological contexts.

Other volumes are the result of a series of conferences at the University of Lund, Sweden. The first, World System History: The Social Science of Long Term Change, was also held in 1995 (Denemark et al. 2000). As noted earlier, chapters by Denemark and by Thompson review and compare various approaches to macrohistorical theorizing, including WSA. The second conference, World System History and Global Environmental Change, was held in 2003. The focus in the second conference was on environmental issues broadly conceived (Hornborg and Crumley 2007; Hornborg et al. 2007). Contributors outlined many different approaches, including WSA, to long-term change from several different disciplines. This brief history documents the considerable expansion of world-systems analysis into prehistory and other areas and a continuing dialogue with other approaches to long-term social change. 


\section{Applications to European prehistory}

Various scholars have utilized WSA explicitly in their analyses of societal interaction in prehistoric Europe (including the circum-Mediterranean region). Kristiansen $(1998 \mathrm{a}, \mathrm{b})$ has discussed the developments in Europe from the second to the first millennium $\mathrm{BC}$ in the context of an emerging world system. He posits several key components of this system. First, he argues that the Mycenaeans served "as transmitters and receivers of new influences between the east Mediterranean and Central Europe. We propose that they rose to power through their ability to provide useful goods to both parties, and thereby created a new competitive niche" (Kristiansen 1998a, p. 360). Kristiansen (1998a, p. 361) argues that the Mycenaeans forged connections between the Aegean and the Black Sea, with extensions up the Danube to the Carpathian region, which created "the cultural koine of the Aegean/ eastern Europe." Trade contacts expanded to the central and western Mediterranean in the period 1500-1200 BC. In all, "The historical sequence reflects a development from small-scale luxury trade in the early phase (tin, amber and gold) towards largescale bulk trade in commodities-including copper-in the late period" (Kristiansen 1998a, p. 364). He identifies two other key factors in this process: the rise of metallurgical centers, from c. $1900 \mathrm{BC}$ on, and the emergence of warrior elites as part of "indirect centre-periphery dynamics" (p. 378).

Kristiansen (1998a, p. 389) sees the development of a regional exchange system in the Late Bronze Age in which there was a "closer periphery ... integrated into the Mycenaean economy," demonstrated in the distribution of Mycenaean pottery from western Anatolia to Italy, and a "secondary periphery, where Mycenaean body armour and skill in metal craftsmanship were adopted." He concludes that a world system emerged from the interaction between the Near East, the Mediterranean, and central Europe c. 2000 BC, which was reflected in social, cultural, and economic "regularities" (Kristiansen 1998a, pp. 394, 418). The relationships between centers and peripheries changed over time between two forms, with elite control of sedentary loci of metal production and dispersal at one pole, and decentralized warrior societies at the other (Kristiansen 1998a, pp. 412-415, Fig. 225). Rowlands (1998, p. 237) argues for something similar when he suggests that centers and peripheries experience alternating expansion and contraction. Chase-Dunn and Hall (1997) refer to this process as pulsation.

\section{The Aegean}

Kardulias (1999a) used WSA to explain general trade in the Bronze Age Aegean and the production and distribution of flaked stone tools during the same period (Kardulias 1999b, d), and to analyze the results of a survey in Cyprus (Kardulias 2007; Kardulias and Yerkes 2004). Initially he suggested that the Aegean system consisted of multiple levels (internal, intermediate, and long distance) that linked local, regional, and international communities. The materials exchanged within and between the various units varied, with low-to-medium-value bulk goods (e.g., obsidian for tool production) concentrated in the internal and intermediate levels, and high-value preciosities (and perhaps some bulk goods such as timber) the focus 
of trade between the Aegean and the Near East, including Egypt. The account emphasized the interaction of different communities on Crete that in one sense formed their own insular "world" but that also were connected to other Aegean islands and the greater Near Eastern world-system by means of the shipping routes to the south and east.

Sherratt (1993) commented on world-systems linkages between central Europe, the Aegean, and the Near East. He used the term "margin" to refer to a zone that does not interact directly with a core but provides materials that are critical to the operation of the system. He pointed to the role of amber from the Baltic and various metals from central Europe in the Mediterranean trade. The urban core of the Near East and the Aegean in the Bronze Age stimulated the exchange of many commodities through multiple links without direct contact between members from either geographical location. Sherratt suggested that parts of this system existed in the Neolithic and continued down into historic times, but not without alterations; in this respect, he supports the contention of Chase-Dunn and Hall (1997) that the Afroeurasian world-system originated about 10,000 years ago. To be clear, the latter do not see one system moving forward from the Neolithic. Instead, they claim that world-systems, or better world-system-like structures, appeared at least that long ago. From that point they began growing and merging, developing into the systems we find around the time of Ur, the time at which Frank (1993) began his account. In the Bronze Age, the trade in metals, especially bronze, was particularly significant. The liquidity provided by bronze made possible the integration of "regional exchange cycles." Sherratt suggests that the Bronze Age is aptly named, not simply because of the artifacts but because this metal alloy fueled the economic expansion on which many early states depended.

Of particular importance is Sherratt's concept of the margin "as the area of 'escaped' technologies and long-distance contacts based on directional exchangecycles" (Sherratt 1993, p. 44). He described the Aegean as one of several linked maritime-exchange cycles in the Mediterranean that in the Bronze Age witnessed the shift from "'luxuries' to 'commodities' in the context of the emergence of palatial organisation" (Sherratt 1993, p. 45). The relatively rapid development of production centers and the concomitant supporting organizational structures moved the peoples of the Aegean from the status of periphery to "more equal participation in inter-regional trade" (Sherratt 1993, p. 45). This process fostered the growth of trade in bulk materials. More recently he advocated a "return to the global perspective that prevailed before the 1960s." He urged his colleagues to think about interaction on a continent-wide scale. Grand reconstructions can be seen as "the outcome of human actions-distant from our own experience but nevertheless comprehensible in terms of common human motivations, propensities, and acts of will" (Sherratt 2006, p. 53). Indeed, Kardulias (1999d, p. 70) argues, "In reply to Sherratt's (1993) query, What would a Bronze Age world system look like?, the Mycenaean world system was multitiered, with some central elements and activities, while others were decentralized." This is precisely the kind of question and issue that WSA helps address; it also provides a number of hypotheses and putative mechanisms driving such changes. Examination of these changes can help us achieve a better assessment of the range and variation of these processes and 
relations. This also will allow further questions about how and the degree to which peripheral or marginal areas shaped the overall system and core areas.

Berg (1999) discusses the Aegean exchange network in WSA terms. She uses the number of contacts between regions to indicate the relative position of each in the exchange system. Pottery is the key artifact type used to determine presence and strength of contact, with metals and other objects used when available. She argues that a nonhierarchical core/semiperiphery relationship characterized the Middle Bronze Age, with peer polities involved in active trade. Beginning in the Late Bronze Age, the relationships tended to become more unequal as a "battle between the two strongest powers [Crete and the mainland] resulted in the marginalisation of most other islands in the Aegean" (Berg 1999, p. 481). Berg argues that other islands still engaged in the system. Because there was an ongoing competition between the major players, the smaller partners maintained the ability to be active rather than passive participants.

Here we have an instance where a specific kind of world-system gave more autonomy to peripheral areas. What we do not know is how common this sort of relationship was, and if there are other ways by which such autonomy was both generated and maintained. Beyond this, there are questions about how cores eventually began to exert more control and curtail peripheral autonomy.

From these examples we can see that to equate WSA exclusively with the early writing of Wallerstein does a grave injustice to the various insights that have grown from the original discussion. Not only does such a dismissal ignore work by worldsystems analysts, it minimizes the positive contributions many archaeologists have made to refining, elaborating, and emending WSA.

\section{WSA and archaeology: Opportunities and challenges}

We now turn to recent examples of the disconnect between archaeology and WSA and indicate what has been missed and what might be gained by forging stronger links. We issue a strong caveat though: all the papers we discuss here are excellent and well worth reading, despite our comments or critiques.

Two papers by Greaves $(2007 a, b)$ that "flirt with" WSA have not pursued it very far, yet could profit from doing so (Greaves 2010 pursues WSA in more detail). Greaves (2007a) reexamines the notion of Anatolia as a bridge between East and West. He notes that the metaphor of a bridge more or less tacitly assumes a divide to be overcome. A bridge is often seen as a passive object as opposed to a point or region of interaction: “... bridges are essentially inanimate objects that do not change, nor are changed by, that which passes over them" (Greaves 2007a, p. 3).

Greaves goes on to say that "... scholarly writing about the prehistoric 'Aegean' $\ldots$ is frequently written about without reference to the west coast of Anatolia. ...In so doing, Aegean prehistorians are retrojecting the contemporary fault-line created by the modern Greek-Turkish border onto ... the past ..." (Greaves 2007a, p. 4). This divide originates in the Persian wars (499-477 BC), which are the point “... at which the division between East and West crystallised and became enshrined in the creation of 'Greek' and 'Barbarian' as diametrically opposed ideals" (Greaves 
2007a, p. 4). This is an instance of what Guy and Sheridan (1998b) call "ethnographic upstreaming," that is, projecting the present into the past. This problem is not limited to ancient Anatolia, or colonial northern New Spain (Guy and Sheridan 1998a; Hall 1989; McGuire and Villalpando 1989; Villalpando 2002; Wilcox et al. 2008).

In a somewhat different way, this approach contributed to a distorted history over millennia of pastoral-sedentary interactions at the edges of central Asian grasslands. Barfield (1989) did much to correct this in The Perilous Frontier, in which he examined all frontiers in perspective (Barfield 1990, 2001a, b, c; see also Hall 2000c). Several points are germane here. First, most studies of central Asia (Christian 1998 is a notable exception) have been by regional specialists along only one border, typically from the perspective of the sedentary state. Second, Barfield is often criticized for overgeneralization (e.g., Di Cosmo 1994, 2002) by regional specialists who know one border but not the others (see Beckwith 2009a). Third, he approached his analysis from years of working with contemporary nomads in Afghanistan. Barfield was very careful to avoid ethnographic upstreaming, but he did rely on his first-hand experiences with nomads to interpret various documents written from the perspective of a sedentary society. Fourth, he was forced into library research because of the Afghan war with Russia.

Greaves (2007a, pp. 1-2) argues, "Ancient Anatolia is now recognized, not as a passive conduit for communications between the East and the West, but as a region of great diversity that was an active participant in such communications." He later notes that this putative divide is exacerbated by the all too frequent divide between classical archaeologists focusing on "great traditions" and "new archaeologists." He says, "In both regions, scholars apparently look to areas outside Anatolia: on the Aegean coast they look west towards the Aegean, while in the Euphrates Valley they look southeast towards Mesopotamia. Such attitudes served to de-value the study of Anatolia and the recognition of its own rich regional diversity" (Greaves 2007 a, p. 10). He concludes, "Only if we recognise the role that history, both ancient and modern, plays in the construction of communities' knowledge and preconceptions about modern Turkey, and consequently ancient Anatolia, can we begin to open up a richer interpretative framework" (p. 11).

Although Anatolia often does bridge this putative divide, “... it never does so passively, and only through the prism of its own rich cultural traditions." In the context of a discussion of the pros and cons of WSA, Greaves (personal communication, 2007) argues "that the different communities of practice in eastern and western Turkey have both found themselves in what they identify as bridging the 'periphery' of a core located beyond the borders of Turkey - i.e. Mesopotamia and the Aegean."

WSA can help with this problem in two ways. First, contemporary WSA addresses the forces and factors that shape and reshape the modern divide within a larger context of systemic interactions. Wallerstein (1974) himself has been critiqued for seeing the boundary of Europe at Turkey (see inter alia Abu-Lughod 1989). Second, the concepts of contested peripheries (Allen 1992, 1997, 2005; Berquist 1995; Cline 2000) and negotiated peripheries (Kardulias 2007; Parkinson and Galaty 2007) are useful in understanding how and why ancient Anatolia links 
regions. A close examination of contested peripherality in Anatolia offers the opportunity to refine, emend, and further develop WSA based on the examination of disputed frontiers and negotiated peripherality. This is, and should be, a two-way street.

We see this in a minor way in Greaves's (2007b, 2010) discussion of Milesian colonies on the Black Sea. He discusses the baggage that the term "colony" carries and notes the problem that much trade is invisible in the archaeological record (Gosden 2004 elaborates on this issue). Based on different population estimates, Greaves follows the work of others to argue that land hunger, due to conquest and confiscation, pushed the formation of colonies. It is difficult to make the case for trade, rather than lack of land (i.e., population pressure), since many of the trade goods are archaeologically invisible or can only be inferred from the remains of the vessels presumably used to convey them. He further argues that oracles helped individuals decide to leave and justified their doing so. Implicit in this argument is an assumption that trade had brought knowledge of suitable sites but that it was not the prime motivator. He also presents clear evidence that "historical records can be positively misleading" (Greaves 2007b, p. 19) as to the metropolitan origins of various colonies. He also notes that use of WSA in exploring these topics must be done cautiously (cf. Tsetskhladze 2003, 2006). Indeed, he is correct in this. We would go further and reverse the process and argue that cases like this can be used to help us better understand processes and causes of expansion of world-systems. The linkage to individual or family decisions based on consultations with oracles points to links between migration, politics, and trade with both individual agency and ideology.

In these articles Greaves is sympathetic to but not closely familiar with WSA. The next two articles offer a contrast. Parkinson and Galaty (2007) not only are familiar with WSA but use it in new ways that are helpful to WSA. Kohl (2008), to use his own term (Kohl 1987), "abuses" WSA by using it as a straw man. We agree with many of his arguments and note that WSA is not the only approach used as a straw man. Kohl makes a somewhat different point to an archaeological audience. While he did not throw the baby out with the bath water, the poor kid is barely hanging on. We also admit that we in turn are using his article as a straw man to make our points.

In contrast, Parkinson and Galaty (2007) not only use but extend WSA in their analyses of state formation in the prehistoric Aegean. They set out to explore and understand processes of secondary state formation. This derives from a common distinction between pristine states and secondary states. Pristine states are those that develop in the absence of contact with previously existing states. This seems to have happened between four and eight times. The key point here is that this is a repeated process, so it probably has some general as well as specific, local causes. Secondary states (sometimes called reactive states, but the term is awkward, suggesting an unintended political tone) are those that develop from nonstate societies, typically but not exclusively chiefdoms, in interaction with already existing states.

The link to WSA is immediately obvious. Indeed, these new states sometime succeed older core states that engendered their formation. This is the "marcher state," semiperipheral development process (Chase-Dunn and Hall 1997, Ch. 5). In 
anthropological archaeology, secondary states were not often investigated since they were "derivative." Parkinson and Galaty argue that these states were, in fact, different from surrounding pristine states, especially in the first generation. Among other observations, they note "that they were not preceded by a period of competing chiefdoms" (Parkinson and Galaty 2007, p. 119, our emphasis). Their argument is worth quoting at length (p. 121; citations from the original):

From a world-systems perspective, the organizational changes that occurred during the Neopalatial period accompany a shift in Crete's position in the eastern Mediterranean interaction sphere. In the Protopalatial period, Crete operated on the periphery of the Near Eastern and Egyptian cores, but in the Neopalatial period, the island filled a semiperipheral position between the Near East and Egypt and the emergent centers on the Greek mainland. During this transition, the Minoan states established themselves as local cores that extended their influence to the southern Aegean (Kardulias 1999a).

Kardulias's concept of "negotiated peripherality" is particularly useful for understanding the changing nature of the relationship between Minoan and Mycenaean states and their Near Eastern and Egyptian counterparts (Kardulias 1999b, 2001; see also Kardulias 2007 and Morris 1999). In contrast to the original world-systems model of Wallerstein (1974), which emphasized the exploitive relationship between dominating cores and passive peripheries, the concept of "negotiated peripherality" captures the active roles played by people living outside the core (Hall 1986).

This is an excellent example of how WSA analysis can be useful for archaeological problems, and how lessons can be taken from one era and applied-mutatis mutandi-in other eras, a process discussed in both epigraphs. The new semiperipherality was built on trade and connections with Greek elites. This may not seem radical, but it in fact replaces the usual account wherein states developed then pursued trade, rather than the reverse, as is being argued here. Parkinson and Galaty (2007, p. 124) go on to find that "Secondary states formed in two basic manners: as remnants of larger entities that broke up after an initial fluorescence or as competing polities that developed at the edge of more mature complex societies." Parkinson and Galaty (2010) explore some of these issues further in a recent edited volume that examines both the emergence of early states in the eastern Mediterranean with a focus on the Aegean and the nature of their links with surrounding areas. WSA receives carefully considered treatment (both positive and negative) by various contributors and exemplifies the kind of scholarly interchange that this article advocates.

Overall then, this is an excellent example of how both WSA and archaeology can benefit from their complementary usages. Parkinson and Galaty (2007, p. 119) are also careful to note that the Aegean states were unusual in that they developed in the absence of competing chiefdoms, the more common process. Because of this they leave the door open to further theoretical development. An obvious direction for future study would be a careful comparison of Aegean secondary-state formation with the more common secondary-state formation that has occurred elsewhere. Also, they note how the specific organizations of those "entities" that became states 
shaped the kind of states they formed. That is, there is an intense interaction between local and world-systemic processes - the negotiated peripherality-that focuses on local active efforts, thus countering the misguided claim that WSA is only top-down. It is also bottom-up!

Kohl $(2002,2007,2008)$ provides an important contribution to the literature on how states interacted in the ancient world. His studies of Transcaucasia utilize an approach with potentially very broad implications for archaeology and for the anthropology of culture contact. He draws on the concept of a "social field," tracing Wolf's (1982) usage back to its originator, Lesser (1985, pp. 94-95; as quoted by Kohl 2008, p. 496):

... the field concept rather than the concept of society as an isolated or closed system reflects socio-historical processes more accurately - that human contact and patterned interpersonal relations are not restricted to social interactions within a single localized social aggregate, but are a universal constant of social life.

This is Kohl's (2008, p. 496) alternative to "interaction spheres," "peer-polity interaction," or "world systems" models. We argue that interaction spheres, peerpolity interaction, and world systems are all refinements on the concept of a social field that actually specify, in ways that are empirically testable, how such fields work.

In some ways we find his use of these other approaches as straw men, especially WSA, puzzling. In two early articles Kohl $(1987,1989)$ described how, contra the modern world-system, food in the Mesopotamian world system was transported to the periphery to underwrite production of steatite (soapstone) bowls for the lowland core. He also argued that "peripheries or northern frontiers of Transcaucasia and Central Asia, like their Aegean counterpart far to the west, did not palely reflect the light of civilization emanating from the ancient Near East; rather, they stimulated the latter civilized areas and profoundly affected their courses of development" (Kohl 1992, pp. 134-135). These are insightful modifications of WSA. Furthermore, they are ones that should be employed-mutatis mutandis-in analyses of the modern world-system: examining how the periphery shapes core development and how new techniques can originate in peripheral areas.

Also, Kepecs and Kohl (2003) provide an excellent intellectual history of WSA and summarize many details that Kohl ignored in a later paper (2008). One source of the problem may be Kohl's continual reference to a "world-system model." As we have already argued, it is an approach, not a model. It cannot be applied mechanically. It must be used subtly and with nuances. It suggests questions. We assume Kohl does this because he is trying to foreground the "field concept" and not review WSA.

Still, Kohl presents a solid body of archaeological evidence on wheeled vehicles and metal weapons and tools in a fashion that strongly supports and illuminates his theoretical framework. He claims that WST is deficient in its ability to analyze and compare the Eurasian steppes and Mesopotamia/Near East. His critiques of the use of WST in archaeology (see especially Kohl 1987) are both well known and widely cited. Yet he dismisses WSA somewhat cavalierly, primarily citing Wallerstein (1974) and mentioning some later works. Instead he promotes a concept of a social field and a web of interconnections that are the means by which technologies spread, 
arguing that while there may be cores and peripheries, there is little coercion and little unequal exchange. He draws heavily on Wolf's Europe and the People without History (Wolf 1982), a book that strongly influenced Chase-Dunn and Hall (1997). More to the point, many of his critiques actually support the findings and use of WSA. One bone of contention, probably not resolvable, is that Kohl thinks WSA should stay WST á la Wallerstein and apply only to the last half millennium or so. In doing so he ignores the many insights and, more significantly, the many empirical questions WSA raises for archaeologists interested in webs of interconnections. He also thereby tosses out his own important comments and critiques that have had a strong impact on the development of WSA.

Missing in Kohl's brief summary are the following problems, most of which were introduced in Rise and Demise (Chase-Dunn and Hall 1997), but elaborated subsequently. First, Kohl (2008, p. 498) complains that there are different effects on different peoples at different places: "The world systems model cannot encompass both of these contrastive Bronze Age worlds; the Eurasian steppes are not a periphery to the Ancient Near Eastern core," certainly not in the Wallersteinian sense. But contrast this with: "Developments and declines in one area are distinctive from those in another, but they exhibit complementarities that are not fortuitous but systematically interrelated. One detectable pattern is that centers of cultural evolutionary development are not stationary, but rather, shift or replace one another over time" (Kohl 2008, p. 503).

This is precisely the argument of Chase-Dunn and Hall (1997) in their version of WSA. Furthermore, a major contribution to the social sciences from WSA is that it can explain why what are supposedly universal and uniform social processes can be different, indeed opposite in different places. A classic example is Ward (1993), who showed how development in the core has opposite effects on fertility from development in peripheral areas. In her edited collection (Ward 1990), she shows that these differences, with underlying similarities, manifest themselves in each peripheral area in ways that correspond to local conditions. This is something social field analysis cannot do. In short, WSA is not universalizing; it is a paradigm for asking questions. Additionally, it is one that takes specific, local conditions seriously. Besides asking how cores affect peripheries, it asks how peripheriesboth in general and for specific peripheral areas-shape both the core and the overall system. That is why this cavalier dismissal is so puzzling; it does exactly what Kohl claims for social fields but with far more specification, specification that is not confusing or confounding but subject to empirical study.

Another aspect of WSA in the ancient world is that systemness itself is a variable quality. How coherent is a system? How does it change its level of coherence, becoming more or less coherent? This remains an open empirical as well as theoretical issue. The loose webs, Kohl and others note, may be inchoate worldsystems, or as Kohl implies, they may be something else. That, however, is an empirical question whose answer or answers have important theoretical consequences.

Chase-Dunn and Hall (1997, Ch. 5, esp. p. 78) argued that there are many possible kinds of semiperipheries: regions that mix core and peripheral forms of organization; regions spatially located between core and peripheral regions; regions 
located between two or more competing core regions (later labeled contested peripheries by Allen [1997, 2005]); regions in which mediating activities linking core and peripheral areas take place; and regions in which institutional features are intermediate in form between those found in adjacent core and peripheral areas.

Again, the number, kinds, and variations among semiperipheries are empirical and theoretical issues that merit further investigation, not out-of-hand dismissal. Semiperipheral areas, especially marcher states, are places where system change happens most frequently. Marcher states are those located on the fringe of a system, that in taking over the system sometimes become a new core, shifting the core both politically and geographically. Such marcher states, or semiperipheral areas, have distinct advantages. First, since they are often on the edge of the system, they do not need to be concerned about defense from all sides, unlike core areas that are subject to contestation from many sides simultaneously. Second, they typically have sufficient contact with core areas to have a solid command of core technologies, including technologies of power (or social organizational innovations). Simultaneously, however, they are not as heavily invested in these core technologies, do not have elites whose position depends on maintaining the status quo, and so are freer to experiment and develop new forms of social organization. This is why semiperipheral areas are often seedbeds of change-they serve as zones of innovation. This does not occur in all cases but is more common there than in core or peripheral parts of the system (Chase-Dunn and Hall 1997, Ch. 5; Chase-Dunn and Inoue 2010; Chase-Dunn et al. 2006, 2010; Love et al. 2010).

Chase-Dunn and Hall (1997) draw a distinction between core-periphery differentiation, wherein different kinds of societies interact on a relatively equal footing, and core-periphery hierarchy, wherein these different societies become hierarchically interconnected. Kohl's comment about Eurasian steppes and Mesopotamia/Near East is precisely an instance of core-periphery differentiation. Not all instances of core-periphery differentiation become core-periphery hierarchies. How, why, and when such transitions do occur is an open question, empirically and theoretically. Ironically, the instances Kohl discusses could be used to begin to tease out some initial answers to this question.

In an extended discussion of ideology and landscape of Chaco Canyon, Van Dyke (2007) makes a number of comments that point to ways in which analyses of ideology might be used to investigate the transformation from core-periphery differentiation to core-periphery hierarchy. She notes that at various times there seems to have been an increase in inequality among Chacoans and between Chacoans and their outliers. Such a shift is suggestive of the differentiationhierarchy shift: "The shift toward hierarchy did not take place suddenly, nor is it attributable to a single causal factor. Rather, Chaco emerged as a center place and Chacoan ritual leaders gained social and political power as the result of the negotiation of ideas, landscape, and social history" (Van Dyke 2007, p. 105). She also notes in many places that even when gradual, cumulative change originates in individual decisions, these must be placed in their larger historical context (e.g., Van Dyke 2007, p. 251).

These changes are embedded in something that to us sounds like at least a nascent, if inchoate, world-system: "Classic Bonito architectural and political 
developments in Chaco Canyon cannot be understood outside their larger social context - a world comprising contemporaneous outlier communities stretching across northwest New Mexico and adjacent areas (Van Dyke 2007, p. 21). She also notes that "The canyon was the center of a redistribution network for subsistence goods - the network protected everyone in the San Juan Basin against unpredictable crop shortfalls due to rainfall fluctuations" (Van Dyke 2007, pp. 26-27). This is the larger setting within which the gradual shift from differentiation to hierarchy, as marked by increasing inequality, occurs. This certainly offers some tantalizing insights into how core-periphery differentiation might become core-periphery hierarchy. No doubt similar processes occurred in other places and other times. It is also quite likely that there may have been other mechanisms that gave a similar result.

Van Dyke also notes that "It is important to consider time in our reconstructions, at multiple scales. Eleventh-century events at Chaco Canyon cannot be understood outside the context of some five centuries of earlier developments" (Van Dyke 2007 , p. 252). This is suggestive of world-system time, by which we mean that different aspects of world-systemic processes occur along different time scales (see below and Hall 2009). What is most intriguing in Van Dyke's account is how ritual, landscape, and architecture may be used as clues to various processes. In particular, her concept of intervisibility, meaning that major sacred buildings are within line of sight of each other, may define "the boundaries of the Chacoan World" (Van Dyke 2007, p. 180). This is at least suggestive of ways in which world-systemic boundaries, both internal and external, might be marked. Finally, her discussion repeatedly notes how what are typically viewed as social structural processes often play out on the ground in ritual and sacred terms. Clearly, world-systemic processes might be investigated by means other than solely through examination of trade patterns.

We return here to Schneider's (1977) critique of Wallerstein (1974), noting that trade in luxuries or prestige goods is important and can play major roles in system change. Many writers have suggested that whether a good is a luxury or bulk good is more a consequence of its economic and technological context than a property of the good itself. Allen $(1997,2005)$ suggests that these are really poles of a continuum rather than unlinked opposites. Again, this is an issue worthy of further investigation. Turchin and Hall (2003) use biological population models to show how very low-level connections, as in trade in scarce luxury goods, can bring the various cycles of two very loosely connected systems into synchronization. Indeed, the entire issue of East-West synchrony across Afroeurasia was first raised in WSA in Rise and Demise but had its origins in Teggart's (1939) observations that changes across Eurasia seemed to occur synchronically, despite the absence of clear connections. A series of papers have explored this issue in some depth. It seems that the apparent synchrony of the largest East-West cities was due to poor data (Hall et al. 2009), but the synchrony of the largest East-West empires' rise and fall is robust (Chase-Dunn and Manning 2002; Chase-Dunn et al. 2000). This is a topic of continuing research. Ironically, it is archaeologists who are best placed to shed empirical light on these processes, which are not unique to Afroeurasia. A similar synchrony has been noted between the timing of the collapses of southwestern and 
southeastern chiefdoms in precolonial North America (Neitzel 1999). The point here is that all networks are problematic, especially with regard to how "things" are transmitted, and the ways those transmissions occur are critical empirical and theoretical problems for understanding cycles of states, empires, and world-systems.

As we noted in the discussion of Parkinson and Galaty (2007), state formation is a system process that is closely connected to processes of incorporation of new areas and/or new peoples into world-systems. Hall $(1986,1989)$ argued that incorporation is a complex continuum that has empirically fuzzy beginnings and is somewhat reversible, but it does tend toward increased incorporation over time. Others have expanded this concept considerably (Bush 2005a, b; Carlson 2001, 2002; Dunaway 1996a, b, c; Hollis 2004, 2005). It is in the process of incorporation that local peoples, especially nonstate peoples, are able to resist and/or shape the process. Zones of incorporation are frontiers (Hall 2000c, 2002b, 2009), where all social relations are to some extent up for grabs. It is on frontiers that active resistance, occasionally successful, by people in peripheral areas is most visible. In fully incorporated areas, which are what most of modern world-systems analysts study, that resistance, while still present, is often attenuated severely and is difficult to see. Archaeologists who study borders and chiefdoms or tribes are well placed to fill in evidence and theorize on these topics.

This is precisely what Parkinson and Galaty (2007) have begun to do with regard to state formation. Kardulias (2007, p. 55) built on the analyses of incorporation to develop a concept of "negotiated peripherality"- "the willingness and ability of individuals in peripheries to determine the conditions under which they will engage in trade, ceremonial exchange, intermarriage, adoption of outside religions and political ideologies, etc. with representatives of expanding states." He does this by a careful comparison of such processes between the fur trade in northeastern North America and the complex roles of Cyprus in ancient interactions in the eastern Mediterranean.

The concept suggests that people in peripheral areas selectively adopt or reject a variety of symbols, artifacts, foodstuffs, and behaviors after they assess the value of these items. As is often the case with such decision-making processes, people frequently choose options on the basis of the perceived benefits of either (1) adopting some new form, (2) retaining an old or traditional practice or object while simultaneously rejecting the foreign version, or (3) crafting some mixture of the traditional and exotic by amalgamating elements into a hybrid type. In each of these ways of negotiating, people may have both short-term and long-term goals. Although the short-term consequences (both positive and negative) of selecting one option can often be judged with some degree of certainty, there are often unintended or unforeseen long-term consequences. Even a decision that brings immediate benefits may in the long run prove costly to a group on the periphery. For example, many Native American groups initially benefited from the European objects that participation in the fur trade conferred on them, but their involvement eventually led to considerable dependence on a technology over which they had little control; the loss of autonomy was a consequence of adopting metal artifacts, firearms, and other items (Kardulias 2007). The fur trade example also demonstrates the inverse relationship between degree of incorporation and ability to negotiate. As incorporation increases in 
intensity, the ability of people on the periphery to negotiate with core peoples decreases. One final aspect of negotiation is that it can be conducted at the individual or corporate level. In the former, each person might be responsible for determining the acceptability of a transaction; in the latter, someone (or a restricted group) acts as the spokesperson for those on one side or the other (and occasionally both sides) of a negotiation. We should expect to see a higher degree of individual negotiation when the peripheral society is a foraging group, whereas corporate negotiation would characterize the interactions of some tribal and chiefdom peripheral groups.

Finally, we do not claim that WSA should replace all other approaches to macrosocial change. Our claim is far more modest, that WSA should be part of the theoretical armamentarium for studying evolution, convergent or divergent, and for studying economic, political, social, and cultural change in the long term.

There are a few other more minor points that warrant comment. Kohl (2008, p. 497) argues that "This network of interconnections during the Bronze Age, however, did not constitute a single unit, an inchoate version of the modern 'world system." Almost no world-systems analysts argue for a single world system in antiquity. The sole exception might be Frank (1993), who does argue that there has been one world system for the last 5000 years (Frank and Gills 1993). Chase-Dunn and Hall (1997), among others, discuss how different world-systems merge, often at broader levels but not at narrower levels, and then often break back apart (ChaseDunn and Hall 1997, Ch. 4; Hall and Chase-Dunn 2006). This issue is serious: how did the contemporary global world-system emerge from a number of isolated or, at best, loosely connected world-systems?

Kohl (2008, p. 497) further argues that "The boundaries of the system also shift over time in a manner that reflects not simply continuous growth but also the conscious development of new areas of intense interaction ... ." No one claims there was one continuously growing system. Rather there were many. Some were linked only by trade in luxury goods or through the spread of ideas and ideologies. Others were linked via regular political-military interaction, and only in the modern world-system were they linked in the trade of bulk goods. These networks expand, contract, break down, and rebuild repeatedly. These processes, however, cannot be understood only locally - a point on which we and Kohl agree. But we argue there is more to this than a social field. Even spider webs have boundaries. Indeed, Smith (2005, p. 838) argues: "In sum, contemporaneity in archaeological and historical maps should be viewed as the hypothesis upon which further research is based, rather than an immutable conclusion about the relationship among sites." For further discussions of boundaries see Stark's (1998) collection and Parkinson (2006).

Finding the limits of a system is difficult, but in principle they can be determined empirically. If one made a topographic map of interactions, there are areas where density decreases sharply. These are boundaries. Admittedly, this is very difficult to do in the ancient world and in prehistory. It has been done, however, for the modern world-system, and even now there are distinct boundaries. In a discussion of bioregionalism, Chew (2008) notes that boundaries of bioregions are marked by changes in density of flora or fauna. "As a benchmark indicator, if about 15 to 25 percent of the animal and plant life changes from one region to another, then this 
would demarcate the boundaries of one bioregion with another" (Chew 2008, p. 39). This is more precise than is possible for bounding ancient world-systems, but the principle is the same. How and why these changes occur are empirical and theoretical problems. These are problems that archaeologists are particularly well equipped to study, if they will ask the questions. We now turn to two creative examples of the use of WSA.

\section{Creative use of WSA: Smith and Berdan on Postclassic Mesoamerica}

Smith and Berdan (2003a) edited a volume devoted to Postclassic Mesoamerica that made extensive use of WSA and, in several instances, suggested modifications growing out of the Mesoamerican context. Their goal was to examine "a precapitalist world system in that it was a large-scale zone of economic and social interaction that tied together independent polities, and these interactions had significant impacts on the participating societies" (Smith and Berdan 2003b, p. 4). They noted (p. 12) that WSA "is one of the few approaches capable of encompassing an area as large as Mesoamerica while accommodating a wide range of variation in the economic and political organization of the constituent societies." They use the network bounding suggested by Chase-Dunn and Hall (1997) to describe Mesoamerica.

In the Smith and Berdan volume, Kepecs and Kohl (2003) present an excellent summary of WSA, far surpassing Kohl's 2008 article. Kepecs and Kohl (2003, p. 15) see WSA as "way out of static diffusion/migration models" and note that "ancient peripheries sometimes possessed technologies on which cores depended." They further argue that the core-periphery differentiation and core-periphery hierarchy distinction is useful and that underdevelopment is not as important in premodern systems as in the modern world-system. They also suggest that in addition to more typical peripheries, there also are unspecialized peripheries and resource-extraction zones (see also Smith and Berdan 2003c). Finally, while Kepecs sees WSA as a corrective to past misconceptions, Kohl (2008, p. 19) "worries about lack of correspondence between model and reality." This is the only point in this discussion where we would demur. As noted above, WSA is not a model to be applied mechanically. It is a form of analysis for generating interesting and useful questions.

Smith and Berdan (2003c) discuss the spatial structure of Mesoamerica, noting that they would now place more emphasis on far peripheries and their systemic effects on the overall system. They argue for further conceptual refinement and suggest that there are resource-extraction zones, unspecialized peripheral zones, and contact peripheries. We concur and note that Hall (1989) and Chase-Dunn and Hall (1997, Ch. 4) have described incorporation as a variable process that ranges from minimal contact to complete incorporation. Their concepts of unspecialized peripheral zones and contact peripheries are refinements to the original notion. Their finding parallels the argument by Turchin and Hall (2003) that even minimal contact can have important systemwide impacts. Both groups reached this conclusion independently, which suggests that it has some robustness. 
Smith and Berdan (2003c) also note that while in principle it is possible to bound world-systems and zones, in practice it is difficult to do so. This conclusion is echoed by Pollard (2003), who suggests a variety of ways to bound world systems. She argues that the edges are unclear, as did Chase-Dunn and Hall (1997). Here we would add, following Kardulias (2007), that it is precisely this fuzziness of worldsystem edges that facilitates negotiation of the terms of incorporation. This also seems to be a more or less general characteristic of frontiers (Hall 2000c, 2009). Our claim is that the boundaries are fuzzy empirically, and that fuzziness needs both further empirical investigation and further conceptual and theoretical development. Pollard (2003) has made some progress in addressing this, as has Parkinson (2002a, b, 2006).

Smith and Berdan (2003c) build on this discussion to examine the Aztec empire. Following Abu-Lughod (1989), they argue that there are many overlapping and interlocking subsystems of exchange and that the edges are often zones of creativity. They note that there are at least four different ways of absorbing new areas and peoples: conquest incorporation, regional political geography, use of local resources, and local ruler responses. Despite these strategies of control, economic exchanges of "turquoise, copper, obsidian, and perhaps other goods moved from west to east into conquered Aztec provinces" (Berdan and Smith 2003a, p. 71).

Berdan (2003a) then analyzes the eastern borders of the empire, noting that boundaries are complex and multidimensional, varying in intensity, stability, and permeability. She concludes that borders are shaped by level of political interest, distance, competing cores, specialized relations, proximity to contact peripheries, and time of control. Again this converges with world-system analyses of frontiers in general (Hall 2000c, 2009).

Smith (2003a, b) examines commodity and information exchanges. For both, he finds a network approach useful. He further notes that the quality of a commodity as bulk good or luxury is as much a function of its roles in the systems of exchange as a property of the object itself. Analogously, the value of information is shaped by its roles in the overall system.

Berdan (2003b) studies various subregions and finds, paralleling Kohl's (1987) finding, that some peripheral areas are not always exploited. She also looks at intermarriages and notes how local elites retain, or even gain, in status through their relations with the core. Smith (2003b) conducts a similar analysis of cores, discussing the formation of the Triple Alliance and the Pax Azteca.

Kohl and Chernykh (2003) make a detailed comparison of two hemispheres. Three points stand out. First, "trade in exotic luxury goods was structurally more significant relative to the trade in bulk staples than is characteristic of the modern world system" (pp. 307-308). Second, "development of underdevelopment" was less intense in both ancient systems. Third, "For both hemispheres, it is impossible to understand development in a single region without considering the interconnection - the exchanges of materials and the movements of peoples - between regions" (p. 312). This seems to fly in the face of Kohl's (2008) recent discussion. All three differences, in fact, precisely demonstrate the value of using WSA to investigate ancient settings.

Berdan et al. (2003) have, in fact, now fleshed out some of these differences, allowing further refinement of WSA and generating a myriad of comparative 
questions. They conclude that "None of these approaches [migrations, conquests, diffusionism, trade, spread of stylistic traits, Polanyian substantivism] contain the breadth and flexibility of the world-system approach, particularly as conceived and modified in this book" (p. 313).

In a somewhat similar way, Filini (2004) applies world-systems analysis to the Cuitzeo Basin and Teotihuacan in creative ways. She finds that peripherality and dependency need to be problematized and understood on the basis of empirical evidence. She also notes, much like Kardulias (2007), that there is considerable room for negotiation. She argues that symbolic or informational connections are sufficient to define a system. Finally, Filini develops some useful archaeological techniques for measuring peripherality.

These examples are some detailed and insightful uses of WSA in a premodern context. Along with Kardulias (2007), Parkinson and Galaty (2007), and Greaves (2007a, b, 2010), we see how WSA can be used to ask useful questions and search out answers, not only to what happened and why but to add further refinements to WSA.

\section{Rethinking system demise: Chew on environment and climate change}

In a trilogy of books, Chew $(2001,2007,2008)$ explores the roles of environmental factors, ecological relations, and climatic shifts on world-systemic processes and seeks to gain insights into shifting relations between nature and culture. We are aware that there is considerable controversy about his findings, especially the second volume (Chew 2007), particularly among archaeologists. We also note that the trilogy has been well received among many scholars studying environment and climate change. Rather than entering these controversies, our purpose is to highlight another creative use of WSA that demonstrates how WSA can be expanded to address new issues and problems.

In the first volume, Chew (2001) examines how various early states systematically, if mostly unintentionally, degraded their environments, ultimately leading to their own collapses. Though each case is unique, there are underlying similarities. First, early states and city-states had very large ecological footprints. Their impacts reached to their farthest peripheries, shaped by specific local conditions. Second, in many cases local intelligentsia figured out, to some degree, what was happening and why. Third, most disconcertingly, these analysts were seldom heeded; if heeded, remedial action was far too little and much too late. The short explanation is that the necessary steps to prevent collapse also undermine the status and wealth of existing elites. Fourth, Chew uncovers a previously unremarked approximately 600-year cycle of "dark ages" that follow a collapse. These collapses are almost always devastating for elites (a point also made by Tainter 1988, 2007; Tainter and Tainter 1996). They often can be problematic for commoners too. However, they do generate time for the ecosystem-nature-to recover from devastation due to overexploitation. Fifth, more implicitly, Chew shows that the problem here is "the state," not just capitalist, neoliberal states. The first and fifth similarities are most germane to WSA. The obvious point is that collapse, like much everything else, 
cannot be understood solely locally. One must study the entire world-system. Less obvious is that states, qua states, are a problem.

Chew's second volume (Chew 2007) expands on the discovery of 600-year cycles. It details how and why "dark ages" occurred in 2200-1700 BC, 1200-700 BC, AD 300/400-900, and a fourth dark age that apparently has started at the end of the 20th century (the subject of the third volume). A key consequence of dark ages is that the loss of population, deurbanization, spread of disease, and so forth provide opportunities for developing new states. This may be another mechanism by which world-system centers move. The recovery seldom occurs in the old heartland but somewhere on the edges where collapse is not so devastating. This is congruent with the WSA argument that semiperipheries are often seedbeds of change. In short, dark ages can be times of system transformation. Some are, but others are not. Sorting empirically which dark ages are remains to be done, as well as verifying these 600year cycles. Assuming such verification, the mechanisms and causes of the cycles need to be investigated, and theoretical explanations for them developed. These are issues where archaeologists could make large contributions.

The third volume (Chew 2008) begins to extract explicit lessons from ancient dark ages to understand the dark age we may now be entering. In the book, Chew sees the possibility of a current dark age as somewhat contingent. But in subsequent private communication (2009) he says he is more convinced that we are entering a new dark age. The volume supplies many resources making this argument. One that is especially salient is Kuecker (2007). Chew notes that dark ages do not usually arise suddenly, nor do they end abruptly. They are slow cycles. He argues that the second dark age ("dark age of antiquity") was one of system transformation. He argues that it is thus appropriate to use the dark age of antiquity to understand the dark age now emerging. He does this by an insightful comparison of the rise of Christian monasticism in Europe and the Mediterranean with the rise of bioregionalism in recent decades. Both movements disengage from the world, stressing self-sufficiency and close connections to local conditions. The analysis then draws on this comparison to develop a more abstract model of the conditions of system change. He ends on a surprisingly optimistic note, that the current dark age presents an opportunity to build a better form of human societies.

Chew's trilogy is relevant to the present discussion of WSA in several ways. First, especially in the third volume, it is a model of how to use past processes to gain insight into contemporary social processes. His detailed comparison and analyses of the monastic and bioregional movements show how to use lessons of the past to understand current times by making the appropriate changes to draw out these lessons. He shows how to do the intellectual work suggested by Sabloff in the epigraph to this article. Second, he uses a wide variety of archaeological data-and data used by archaeologists, such as tree ring data, climate data, pollen data, etc.- - to examine world-system processes. Here his examples illustrate how archaeologists can contribute to world-systems analysis via their own work (and, not trivially, reach wider nonarchaeological audiences). Third, he uses WSA as a paradigm, as a way to ask interesting questions. In his hands, WSA is not a model, nor a theory. It offers guidance about what questions to ask and how to ask them. His approach then can be used as an exemplar of WSA in archaeological research. Our argument here 
is not about whether his findings stand up to further empirical investigation, it is about asking these questions. Whatever the final empirical result, we will have learned a great deal about how early world-systems did or did not work.

There is at least one other missed opportunity with respect to WSA. It should have been, but was not until recently, a way to study frontiers.

\section{Another missed opportunity}

Greaves (2007b, p. 19) noted that "historical records can be positively misleading." But there is more to it than that. Following Ferguson and Whitehead (1992a, b), this is a typical consequence of state and hence world-system expansion. First, a small disclaimer: they use "tribal" in a somewhat ironic way, noting that following a great deal of literature, "tribe" is too vague a term. Rather they are referring to what state colonizers call "area." We further acknowledge that their use of tribe, which draws heavily on the work of Fried $(1952,1967,1975)$, is controversial for some scholars. Parkinson (2002b, c, 2006) and others (chapters by Carneiro, Fowles, and Galaty in Parkinson 2002a) provide other approaches.

The "tribal zone" is that frontier or transition zone just beyond the boundary of state expansion into nonstate territories. Ferguson and Whitehead (1992b) make several key points. When states expand, they either absorb or displace nonstate peoples. In either case, the contact ripples out far beyond the region of direct contact, fueled by trade and efforts of indigenous leaders to use access to state goods as a way to garner followers. Those farther down the line seek to bypass the middlemen and often come into conflict with those closer to the state boundary. Wells (1999a, b) notes that hoards of Roman coins and other material goods were found hundreds of miles beyond the limes that marked the limit of Roman expansion into Europe. In the modern world-system, war could be generated by slave or captive trade (see Hall 1989 for detailed account) and/or diseases could spread, and sometimes new technologies, e.g., the spread of horses from the U.S. Southwest or guns from northeastern North America. The chapters in Ferguson and Whitehead (1992a) show that these effects occurred in both ancient and modern times, and with the expansion of any state. This is a useful corrective to the common assumption that capitalism is the only system that does this. Rather, it is "more efficient" at it.

The second consequence is that the first literate observers, almost always from states, were not observing pristine conditions. Instead, they observed conditions that had been vastly changed by state contact. A familiar example is that Lewis and Clark encountered indigenous peoples in the northwest who had had horses for generations, though they were the first Europeans to travel through that area (Fenelon and Defender-Wilson 2004). That being the case, first-hand accounts of life in the "tribal zone" are highly suspect. They need to be corroborated and often revised on the basis of other information, typically archaeological work (see Anderson 1994; Hall 2001, 2006).

Addressing these issues is what has driven much of Hall's (e.g., 2000c, 2009) subsequent work on frontiers. This also suggests that the concept of negotiated 
peripherality and to some extent the concept of contested peripheries are ways to investigate these processes. This is work that often is best, and occasionally only, done by archaeologists (for examples not couched in WSA terms, see Cusick 1998; Gosden 2004; Murray 2004; Parker and Rodseth 2005; Smith and Rubinson 2003; Stark 1998; Villalpando 2002). Archaeological research on frontiers or contact zones or "tribal zones" could contribute much to WSA theorizing, extending or even refuting parts of it. Another, extended historical example is White (1991). Anthony (2007, Ch. 6) presents an elaborate discussion of frontiers, borders, and boundaries and analyzes how and when linguistic and material frontiers might coincide. Many of the techniques that he reviews and applies could be used to map world-system boundaries and frontiers, both within any given world-system and between world-systems.

Hall (2009) explores methods of using WSA for the comparative study of frontiers. The first point is an old canard: the legitimacy of a comparison rests in the purpose of the comparison, not in the entities being compared. Second, worldsystems - because they expand at variable rates and occasionally contract-create, modify, and close frontiers along their various boundaries. Third, frontiers, probably more than any other social locale, cannot be understood solely locally. Their origins, changes, and demises are shaped by external factors and forces. Yet local actions and reactions are crucial to understanding how frontiers form, change, and end. Fourth, frontiers need to be studied in several contexts and scales. Fifth, frontiers often have important impacts on both core areas and world-systems in general.

The major context of a frontier is its location in what might be called worldsystem time. That is, what is happening to the overall system? Is it expanding, contracting, or in a (temporary) steady state? What kind of world-system is it: kin ordered, tributary, capitalist? What are the states of the various world-system cycles: kondratieff, hegemonic, long cycle, dark ages (see Babones 2006; Grimes 2000)? Scalar context can be either geographical or chronological. Some changes originate far from the frontier; others are extremely localized. Over short periods, years or decades, many world-systemic conditions may not vary. Nonetheless, they are in some state or another and usually changing, albeit sometimes at glacial speed. For these situations the conditions may be treated as static or unchanging. However, over a longer time scale, centuries or millennia, these conditions may be changing significantly. Archaeologists work with time scales that can reveal these long-term trends.

The lesson for archaeologists is to consider the many factors that can shape a comparison and to recognize that many of them originate in world-system processes. The final and maybe most important point, if only because it is the most common straw man, is that change goes both ways: from the system to the local area and from the local area to the system. System-to-local impacts often get much more attention because they are easier to discern. But the frontier-to-system impacts are just as important, if not more so, but harder to discern. This is so because the effect of the local on the global may be, for individual frontier locations, infinitesimal or minor. Also, aggregate effects of many or all peripheral areas-here frontiers - may be quite large, even though the contribution of any single locale might be small. 
Finally, we return to the discussions of "tribe" as a concept and as an empirical reality. In addition to issues we raise below, there is a problem with the political connotation of the term "tribe." It has often been used to demean nonstate peoples and as a rationalization for seizing their lands. This is why in the United States many Native American groups have insisted on following early treaty language and being called "nations." This is a serious matter in indigenous relations (see Hall and Fenelon 2009). Furthermore, the term "tribe" is used so vaguely as to become meaningless, a cover term or gloss for any type of nonstate society. Both the political baggage currently attached to the term "tribe" and its very vagueness confuse a different and important debate about tribe as an analytic term, an empirical reality, and a sociocultural evolutionary phase. Fried $(1967,1975)$ went so far as to claim that "tribes" were a form of social organization that resulted from the contact of states with nonstate peoples. They could result either from the consolidation of bands or the devolution of chiefdoms.

Parkinson (2002a, b, c) has taken strong exception to this perspective. He argues, contra Fried, "They [tribes] are real cultural phenomena with measurable attributes that exhibit distinctive patterns." He argues further, "The reason why tribes emerged in some instances of Western contact, and not in others, must have something to do with the structure of their social relations prior to contact" (Parkinson 2002b, p. 7). This, of course, is congruent with a WSA analysis of incorporation that argues that the process is always the result of interaction among the specific forms of social organization among incorporated peoples, the specific core or semiperipheral states doing the incorporation, and the specific conditions of the overall system of which the states are a part. It also points to other conditions under which peripherality might be negotiated (see Kardulias 2007).

But Parkinson (2002b, p. 8) goes further: "An archaeological perspective of tribal social trajectories would suggest, rather, that tribes were a dominant social form on the planet for several thousand years following the end of the Pleistocene." Both Fowles (2002) and Carneiro (2002) argue for "tribe" as a stage or phase of sociocultural evolution. Carneiro begins to develop an analysis of the variations in the forms of tribes. Parkinson (2002c, 2006), in his efforts to disentangle complex, shifting interrelations among tribes in the Hungarian Plain, observes that there is some cycling between more and less integration. He notes, "This process is somewhat reminiscent of the "cycling' often associated with chiefdoms" (Parkinson 2002c, p. 391). He is referring to the work of Anderson (1994) and Marcus (1993). He then notes: "As such, this phenomenon of "tribal cycling, may itself be a criterion useful for distinguishing tribes from other decentralized segmentary, societies (i.e., "bands"), which tend not to exhibit such patterning" (Parkinson 2002c, p. 391).

All this is quite interesting. The cycling of chiefdoms analyzed by Anderson (1994) is clearly a process shaped by interaction of internal and external conditions. Thus, it may be a nascent form of world-system formation (see Hall 2001). Even bands and "tribes" in Parkinson's usage may form very small intersocietal interaction systems, in short, world-systems. Chase-Dunn and Hall (1997, Ch. 6) discussed one such possibility among the Wintu in precontact northern California. Chase-Dunn and Mann (1998) explored this in more depth, using data from place 
names and measurements of hydration rinds on obsidian points to trace the interactions of the "Wintu and their neighbors." The cycling that Anderson, Marcus, Parkinson, and Chase-Dunn and Mann discuss is precisely the kind of cycling that one expects in world-systems. Indeed, cycling, a result of feedback loops, is a key piece of evidence that there is indeed a system (Butzer 1997). Yet Butzer (2005) argues against a Mediterranean world system. Still, these instances of cycling, and even Butzer's description of Mediterranean soil erosion, suggest if not world-systems, at least world-systems-like processes.

Further investigations of these processes can be very useful. First, simply documenting the processes involved would be helpful. Second, they could lead to further insights into processes of sociocultural evolution. Third, they would help deepen the understanding of how intersocietal interaction shapes processes of change. Fourth, they could help delineate the limits of applicability of WSA and contribute many refinements and emendations to analyses of early world-systems. Parkinson has indicated ways in which these processes can be investigated empirically.

\section{Final remarks}

We hope the foregoing discussion convinces many archaeologists that a cavalier dismissal of the relevance of WSA for archaeology is premature. We also have argued that such an attitude leads to myriad missed opportunities. Our argument is not that WSA should trump all other macro-explanatory approaches; it is more modest. WSA should always be included in the mix of approaches. We further argue that one cannot ignore intersocietal interactions, even in the most ancient settings. We remain convinced that WSA offers much in analyzing such interactions, whether or not specific forms of WSA hold up to further empirical research.

We have reviewed some creative and insightful uses of WSA. No doubt we have missed others. We take as a good sign that the number of such studies continues to grow, in both archaeology and other disciplines. One of the difficulties of becoming engaged in debates within and about WSA is that writings are scattered across many disciplines, even more than those reviewed in Hall (2000a). We hope this essay provides some pointer to those debates and suggests many ways archaeologists might enter into them and contribute to further refinement, and in some cases further delimitation, of its applicability to problems of intersocietal interactions.

Finally, we reiterate that WSA is not the "philosopher's stone" for understanding intersocietal interactions and the sociocultural evolution of complex social organization. We further argue that better understanding of that evolution will contribute to better comprehension of the origins of the modern world-system, and we hope it will lead to some insights into its future as globalization continues apace. It is our hope that our discussion opens further dialogue. The water is fine, come on in!

Acknowledgments We acknowledge the comments of many reviewers of various drafts of this article, especially detailed ones by Mike Smith, Mike Galaty, and Alan Greaves, and solid advice from Gary 
Feinman. The usual disclaimer applies: it is not their fault that we did not always follow through on their advice. We are well aware that this is a burgeoning literature and we may well have missed some important recent contributions. Indeed, we would be pleased if any reader who can point to other relevant work would forward that information to Tom Hall (thall@depauw.edu).

Open Access This article is distributed under the terms of the Creative Commons Attribution Noncommercial License which permits any noncommercial use, distribution, and reproduction in any medium, provided the original author(s) and source are credited.

\section{References cited}

Abrams, P. (1982). Historical Sociology, Cornell University Press, Ithaca, NY.

Abu-Lughod, J. (1989). Before European Hegemony: The World System A.D. 1250-1350, Oxford University Press, New York.

Alexander, R. T. (1999). The emerging world-system and colonial Yucatan: The archaeology of coreperiphery integration, 1780-1847. In Kardulias, P. N. (ed.), World-Systems Theory in Practice: Leadership, Production, and Exchange, Rowman and Littlefield, Lanham, MD, pp. 103-124.

Algaze, G. (1993a). Expansionary dynamics of some early pristine states. American Anthropologist 95: 304-333.

Algaze, G. (1993b). The Uruk World System: The Dynamics of Expansion of Early Mesopotamian Civilization, University of Chicago Press, Chicago.

Algaze, G. (2008). Ancient Mesopotamia at the Dawn of Civilization: The Evolution of an Urban Landscape, University of Chicago Press, Chicago.

Allen, M. (1992). The mechanisms of underdevelopment: An ancient Mesopotamian example. Review 15: 453-476.

Allen, M. (1997). Contested Peripheries: Philistia in the Neo-Assyrian World-System, Ph.D. dissertation, Interdepartmental Archaeology Program, University of California, Los Angeles.

Allen, M. (2005). Power is in the details: Administrative technology and the growth of ancient near eastern cores. In Chase-Dunn, C., and Anderson, E. N. (eds.), The Historical Evolution of WorldSystems, Palgrave, New York, pp. 75-91.

Anderson, D. G. (1994). The Savannah River Chiefdoms: Political Change in the Late Prehistoric Southeast, University of Alabama Press, Tuscaloosa.

Anthony, David W. (2007). The Horse, the Wheel, and Language: How Bronze-Age Riders from the Eurasian Steppes Shaped the Modern World, Princeton University Press, Princeton, NJ.

Babones, S. J. (2006). Conducting global social research. In Chase-Dunn, C., and Babones, S. (eds.), Global Social Change: Comparative and Historical Perspectives, Johns Hopkins University Press, Baltimore, MD, pp. 8-30.

Barfield, T. J. (1989). The Perilous Frontier, Blackwell, London.

Barfield, T. J. (1990). Tribe and state relations: The Inner Asian perspective. In Khoury, P. S., and Kostiner, J. (eds.), Tribe and State Formation in the Middle East, University of California Press, Berkeley, pp. 153-182.

Barfield, T. J. (2001a). Steppe empires, China, and the Silk Route: Nomads as a force in international trade and politics. In Khazanov, A., and Wink, A. (eds.), Nomads in the Sedentary World, Curzon Press, London, pp. 234-259.

Barfield, T. J. (2001b). The shadow empires: Imperial state formation along the Chinese-nomad frontier. In Alcock, S. E., D’Altroy, T. N., Morrison, K. D., and Sinopoli, C. M. (eds.), Empires: Perspectives from Archaeology and History, Cambridge University Press, Cambridge, pp. 11-41.

Barfield, T. J. (2001c). Turk, Persian and Arab: The changing relationships between tribes and state within Iran and along its frontiers. In Keddie, N. R., and Matthee, R. (eds.), Iran and the Surrounding World: Interactions in Culture and Cultural Politics, University of Washington Press, Seattle, pp. 61-86.

Beaujard, P. (2010). From three possible Iron-Age world-systems to a single Afro-Eurasian world-system. Journal of World History 21: 1-43. 
Beaujard, P., Berger, L., and Norel, P. (eds.) (2009). Histoire Globale, Mondialisation et Capitalismes, Éditions La Découverte, Paris.

Beckwith, C. I. (2009a). Empires of the Silk Road: A History of Central Eurasia from the Bronze Age to the Present, Princeton University Press, Princeton, NJ.

Beckwith, C. I. (2009b). Epilogue: The barbarians. In Beckwith, C. I. (ed.), Empires of the Silk Road: A History of Central Eurasia from the Bronze Age to the Present, Princeton University Press, Princeton, NJ, pp. 320-362.

Bell-Failkoff, A. (ed.) (2000). The Role of Migration in the History of the Eurasian Steppe: Sedentary Civilization vs. "Barbarian" and Nomad, St. Martin's Press, New York.

Berdan, F. F. (2003a). Borders in eastern Aztec empire. In Smith, M. E., and Berdan, F. F. (eds.), The Postclassic Mesoamerican World, University of Utah Press, Salt Lake City, pp. 73-77.

Berdan, F. F. (2003b). Themes in world-system regions. In Smith, M. E., and Berdan, F. F. (eds.), The Postclassic Mesoamerican World, University of Utah Press, Salt Lake City, pp. 225-226.

Berdan, F. F., and Smith, M. E. (2003a). The Aztec empire. In Smith, M. E., and Berdan, F. F. (eds.), The Postclassic Mesoamerican World, University of Utah Press, Salt Lake City, pp. 67-72.

Berdan, F. F., and Smith, M. E. (2003b). The evolution of a core zone: The Basin of Mexico. In Smith, M. E., and Berdan, F. F. (eds.), The Postclassic Mesoamerican World, University of Utah Press, Salt Lake City, pp. 238-242.

Berdan, F. F., Kepecs, S., and Smith, M. E. (2003). A perspective on Late Postclassic Mesoamerica. In Smith, M. E., and Berdan, F. F. (eds.), The Postclassic Mesoamerican World, University of Utah Press, Salt Lake City, pp. 313-317.

Berg, I. (1999). The southern Aegean system. Journal of World-Systems Research 5: 475-484.

Berquist, J. L. (1995). The shifting frontier: The Achaemenid empire's treatment of western colonies. Journal of World-Systems Research 1: 17(unpaginated).

Blanton, R., and Feinman, G. M. (1984). The Mesoamerican world system. American Anthropologist 86: 673-682.

Bunker, S. G., and Ciccantell, P. S. (2005). Globalization and the Race for Resources, Johns Hopkins University Press, Baltimore, MD.

Burke, E., III, and Pomeranz, K. (2009). The Environment and World History, University of California Press, Berkeley.

Burmeister, S. (2000). Archaeology and migration: Approaches to an archaeological proof of migration. Current Anthropology 41: 539-567.

Bush, C. (2005a). Land, Conflict, and the 'Net of Incorporation': Capitalism's Uneven Expansion into the Navajo Indian Reservation 1860-2000, Ph.D. dissertation, Department of Sociology, Binghamton University, Binghamton, NY.

Bush, C. (2005b). Reconsidering incorporation: Uneven histories of capitalist expansion and encroachment, Native America. Studies in Political Economy 76: 83-109.

Butzer, K. W. (1997). Sociopolitical discontinuity in the Near East c. 2200 BCE: Scenarios from Palestine and Egypt. In Dalfes, H. N., Kulka, G., and Wiess, H. (eds.), Third Millennium BC Climate Change and Old World Collapse, Springer, Berlin, pp. 245-296.

Butzer, K. W. (2005). Environmental history in the Mediterranean world: Cross-disciplinary investigation of cause-and-effect for degradation and soil erosion. Journal of Archaeological Science 32: $1773-1800$.

Byrd, S. C., and Smythe, E. (2010). From the global to the local: Social forums, movements, and place (introduction to special issue). Journal of World-Systems Research 16: 1-5.

Carlson, J. D. (2001). Broadening and deepening: Systemic expansion, incorporation and the zone of ignorance. Journal of World-Systems Research 7: 225-263.

Carlson, J. D. (2002). The 'Otter-Man' empires: The Pacific fur trade, incorporation and the zone of ignorance. Journal of World-Systems Research 8: 389-442.

Carneiro, R. L. (2002). The tribal village and its culture: an evolutionary stage in the history of human society. In Parkinson, W. A. (ed.), The Archaeology of Tribal Societies, International Monographs in Prehistory, Ann Arbor, MI, pp. 34-52.

Castells, M. (2009). The Power of Identity, 2nd ed., Wiley-Blackwell, Malden, MA.

Castells, M. (2010a). The Rise of the Network Society, 2nd ed., Wiley-Blackwell, Malden, MA.

Castells, M. (2010b). End of Millennium, Wiley-Blackwell, New York.

Chase-Dunn, C. (2006). Globalization: A world-systems perspective. In Chase-Dunn, C., and, Babones, S. (eds.), Global Social Change: Comparative and Historical Perspectives, Johns Hopkins University Press, Baltimore, MD, pp. 79-105. 
Chase-Dunn, C., and Anderson, E. N. (eds.) (2005). The Historical Evolution of World-Systems, Palgrave, New York.

Chase-Dunn, C., and Babones, S. (2006). Global Social Change: Comparative and Historical Perspectives, Johns Hopkins University Press, Baltimore, MD.

Chase-Dunn, C., and Hall, T. D. (1997). Rise and Demise: Comparing World-Systems, Westview Press, Boulder, CO.

Chase-Dunn, C., and Hall, T. D. (2009). Changement social et intégration des réseaux d'échange dans la longue durée. In Beaujard, P., Berger, L., and Norel, P. (eds.), Histoire globale, mondialisation et capitalismes, Éditions La Découverte, Paris, pp. 159-188.

Chase-Dunn, C., and Inoue, H. (2010). Accelerating global state formation and global democracy. Paper presented at International Studies Association, New Orleans, February 18 [IROWS Working Paper $\# 55]$.

Chase-Dunn, C., and Mann, K. M. (1998). The Wintu and Their Neighbors: A Very Small World-System in Northern California, University of Arizona Press, Tucson.

Chase-Dunn, C., and Manning, E. S. (2002). City systems and world-systems: Four millennia of city growth and decline. Cross-Cultural Research 36: 379-398.

Chase-Dunn, C., Manning, E. S., and Hall, T. D. (2000). Rise and fall: East-west synchronicity and Indic exceptionalism reexamined. Social Science History 24: 727-754.

Chase-Dunn, C., Hall, T. D., Niemeyer, R., Alvarez, A., Inoue, H., Lawrence, K., Carlson, A., Fierro, B., Kanashiro, M., Sheikh-Mohamed, H., and Young, L. (2006). Middlemen and marcher states in central Asia and east/west empire synchrony. Paper presented at the Research Conference on Middlemen, University of California, San Diego, November 3-5 [IROWS working paper \#30]. Available at http://irows.ucr.edu/papers/irows30/irows30.htm.

Chase-Dunn, C., Hall, T. D., Niemeyer, R., Alvarez, A., Inoue, H., Lawrence, K., and Carlson, A. (2010). Middlemen and marcher states in central Asia and east/west empire synchrony. Social Evolution and History 9: 1-29.

Chew, S. C. (2001). World Ecological Degradation: Accumulation, Urbanization, and Deforestation 3000 B.C. - A. D. 2000, AltaMira Press, Walnut Creek, CA.

Chew, S. C. (2007). The Recurring Dark Ages: Ecological Stress, Climate Changes, and System Transformation, AltaMira Press, Lanham, MD.

Chew, S. C. (2008). Ecological Futures: What History Can Teach Us, AltaMira Press, Lanham, MD.

Christian, D. (1998). A History of Russia, Central Asia and Mongolia, Blackwell, London.

Christian, D. (2004). Maps of Time: An Introduction to Big History, University of California Press, Berkeley.

Cline, E. (2000). 'Contested peripheries' in world systems theory: Megiddo and Jezreel Valley as a test case. Journal of World-Systems Research 6: 8-17.

Curtin, P. D. (1984). Cross-Cultural Trade in World History, Cambridge University Press, Cambridge.

Cusick, J. G. (ed.) (1998). Studies in Culture Contact: Interaction, Culture Change, and Archaeology, Occasional Paper No. 25, Center for Archaeological Investigations, Southern Illinois University, Carbondale.

Denemark, R. A. (2000). Cumulation and direction in world system history. In Denemark, R. A., Friedman, J., Gills, B. K., and Modelski, G. (eds.), World System History: The Social Science of Long-Term Change, Routledge, London, pp. 299-312.

Denemark, R. A., Friedman, J, Gills, B. K., and Modelski, G. (eds.) (2000). World System History: The Social Science of Long-Term Change, Routledge, London.

Diamond, J. (1997). Guns, Germs, and Steel: The Fates of Human Societies, Norton, New York.

Diamond, J. (2005). Collapse: How Societies Choose to Fail or Succeed, Viking, New York.

Di Cosmo, N. (1994). Ancient Inner Asian nomads: Their economic basis and its significance in Chinese history. Journal of Asian Studies 53: 1092-1126.

Di Cosmo, N. (2002). Ancient China and Its Enemies: The Rise of the Nomadic Power in East Asian History, Cambridge University Press, Cambridge.

Dunaway, W. A. (1996a). The First American Frontier: Transition to Capitalism in Southern Appalachia, 1700-1860, University of North Carolina Press, Chapel Hill.

Dunaway, W. A. (1996b). Incorporation as an interactive process: Cherokee resistance to expansion of the capitalist world-system, 1560-1763. Sociological Inquiry 66: 455-470.

Dunaway, W. A. (1996c). The incorporation of mountain ecosystems into the capitalist world-system. Review 19: 355-381. 
Feinman, G. M. (1999). The changing structure of macroregional Mesoamerica: The Classic-Postclassic transition in the Valley of Oaxaca. In Kardulias, P. N. (ed.), World-Systems Theory in Practice: Leadership, Production, and Exchange, Rowman and Littlefield, Lanham, MD, pp. 53-62.

Fenelon, J. V., and Defender-Wilson, M. L. (2004). Voyage of domination, purchase as Conaues, Skakawea for savagery: Distorted icons from misrepresentation of the Lewis and Clark expedition. Wicazao sa Review 19: 85-104.

Ferguson, R. B., and Whitehead, N. L. (eds.) (1992a). War in the Tribal Zone: Expanding States and Indigenous Warfare, School of American Research Press, Santa Fe, NM.

Ferguson, R. B., and Whitehead, N. L. (1992b). The violent edge of empire. In Ferguson, R. B., and Whitehead, N. L. (eds.), War in the Tribal Zone: Expanding States and Indigenous Warfare, School of American Research Press, Santa Fe, NM, pp. 1-30.

Filini, A. (2004). The Presence of Teotihuacan in the Cuitzeo Basin, Michoacán, Mexico: A World-System Perspective, BAR International Series 1279, Archaeopress, Oxford.

Fowles, S. M. (2002). From social type to social process: Placing 'tribe' in a historical framework. In Parkinson, W. A. (ed.), The Archaeology of Tribal Societies, International Monographs in Prehistory, Ann Arbor, MI, pp. 13-33.

Frank, A. G. (1966). The development of underdevelopment. Monthly Review September: 17-31.

Frank, A. G. (1967). Capitalism and Underdevelopment in Latin America: Historical Studies of Chile and Brazil, Monthly Review Press, New York.

Frank, A. G. (1993). The Bronze Age world system and its cycles. Current Anthropology 34: 383-413.

Frank, A. G. (1999). Abuses and uses of world systems theory in archaeology. In Kardulias, P. N. (ed.), World-Systems Theory in Practice: Leadership, Production, and Exchange, Rowman and Littlefield, Lanham, MD, pp. 275-296.

Frank, A. G., and Gills, B. K. (eds.) (1993). The World System: Five Hundred Years or Five Thousand? Routledge, London.

Fried, M. (1952). Land tenure, geography and ecology in the contact of cultures. American Journal of Economics and Sociology 11: 391-412.

Fried, M. (1967). The Evolution of Political Society, Random House, New York.

Fried, M. (1975). The Notion of Tribe, Cummings, Menlo Park, CA.

Friedman, J., and Chase-Dunn, C. (eds.) (2005). Hegemonic Declines: Present and Past, Paradigm, Boulder, CO.

Galaty, M. L. (2011). World-systems analysis and anthropology: A new détante? Reviews in Anthropology 40: in press.

Goldfrank, W. L., Goodman, D., and Szasz, A. (eds.) (1999). Ecology and the World-System, Greenwood Press, Greenwich, CT.

Gosden, C. (2004). Archaeology and Colonialism: Culture Contact from 5000 BC to the Present, Cambridge University Press, Cambridge.

Gould, S. J., and Eldredge, N. (2000). Punctuated equilibrium comes of age. In Gee, H. (ed.), Shaking the Tree: Readings From Nature in the History of Life, University of Chicago Press, Chicago, pp. 17-31.

Greaves, A. (2007a). Trans-Anatolia: Examining Turkey as a bridge between east and west. Anatolian Studies 57: 1-15.

Greaves, A. (2007b). Milesians in the Black Sea: Trade, settlement and religion. In Gabrielsen, V., and Lund, J. (eds.), The Black Sea in Antiquity: Regional and Interregional Economic Exchanges, Aarhus University Press, Aarhus, Denmark, pp. 9-21.

Greaves, A. (2010). The Land of Ionia: Society and Economy in the Archaic Period, Wiley-Blackwell, New York.

Grimes, P. (2000). Recent research on world-systems. In Hall, T. D. (ed.), A World-Systems Reader: New Perspectives on Gender, Urbanism, Cultures, Indigenous Peoples, and Ecology, Rowman and Littlefield, Lanham, MD, pp. 29-55.

Guy, D. J., and Sheridan, T. E. (eds.) (1998a). Contested Ground: Comparative Frontiers on the Northern and Southern Edges of the Spanish Empire, University of Arizona Press, Tucson.

Guy, D. J., and Sheridan, T. E. (1998b). On frontiers: The northern and southern edges of the Spanish empire in America. In Guy, D., and Sheridan, T. (eds.), Contested Ground: Comparative Frontiers on the Northern and Southern Edges of the Spanish Empire, University of Arizona Press, Tucson, pp. $150-166$.

Hall, T. D. (1986). Incorporation in the world-system: Toward a critique. American Sociological Review 51: $390-402$. 
Hall, T. D. (1989). Social Change in the Southwest, 1350-1880, University Press of Kansas, Lawrence.

Hall, T. D. (1999). World-systems and evolution: An appraisal. In Kardulias, P. N. (ed.), World-Systems Theory in Practice: Leadership, Production, and Exchange, Rowman and Littlefield, Lanham, MD, pp. $1-25$.

Hall, T. D. (ed.) (2000a). A World-Systems Reader: New Perspectives on Gender, Urbanism, Cultures, Indigenous Peoples, and Ecology, Rowman and Littlefield Press, Lanham, MD.

Hall, T. D. (2000b). World-systems analysis: A small sample from a large universe. In Hall, T. D. (ed.), A World-Systems Reader: New Perspectives on Gender, Urbanism, Cultures, Indigenous Peoples, and Ecology, Rowman and Littlefield, Lanham, MD, pp. 3-27.

Hall, T. D. (2000c). Frontiers, ethnogenesis, and world-systems: Rethinking the theories. In Hall, T. D. (ed.), A World-Systems Reader: New Perspectives on Gender, Urbanism, Cultures, Indigenous Peoples, and Ecology, Rowman and Littlefield, Lanham, MD, pp. 237-270.

Hall, T. D. (2001). Chiefdoms, states, cycling, and world-systems evolution: A review essay. Journal of World-Systems Research 7: 91-100.

Hall, T. D. (2002a). World-systems analysis and globalization: Directions for the twenty-first century. In Dobratz, B. A., Buzzell, T., and Waldner, L. K. (eds.), Theoretical Directions in Political Sociology for the 21st Century, Elsevier Science, Oxford, pp. 81-122.

Hall, T. D. (2002b). World-systems, frontiers, and ethnogenesis: Incorporation and resistance to state expansion. In Preyer, G., and Bös, M. (eds.), Borderlines in a Globalized World: New Perspectives in a Sociology of the World-Systems, Kluwer/Academic, Dordrecht, pp. 35-66.

Hall, T. D. (2006). [Re]peripheralization, [re]incorporation, frontiers, and nonstate societies: Continuities and discontinuities in globalization processes. In Gills, B. K., and Thompson, W. R. (eds.), Globalization and Global History, Routledge, London, pp. 96-113.

Hall, T. D. (2009). Puzzles in the comparative study of frontiers: Problems, some solutions, and methodological implications. Journal of World-Systems Research 15: 25-47.

Hall, T. D., and Chase-Dunn, C. (1993). The world-systems perspective and archaeology: Forward into the past. Journal of Archaeological Research 1: 121-143.

Hall, T. D., and Chase-Dunn, C. (1994). Forward into the past: World-systems before 1500. Sociological Forum 9: 295-306.

Hall, T. D., and Chase-Dunn, C. (2006). Global social change in the long run. In Chase-Dunn, C., and Babones, S. (eds.), Global Social Change: Comparative and Historical Perspectives, Johns Hopkins University Press, Baltimore, MD, pp. 33-58.

Hall, T. D., and Fenelon, J. V. (2009). Indigenous Peoples and Globalization: Resistance and Revitalization, Paradigm, Boulder, CO.

Hall, T. D., and Kardulias, P. N. (2010). Migration and globalization: Long-term processes in worldsystems. In Jones, T. A., and Mielants, E. (eds.), Mass Migration in the World-System: Past, Present and Future, Paradigm, Boulder, CO, pp. 22-37.

Hall, T. D., Chase-Dunn. C., and Niemeyer, R. (2009). The roles of central Asian middlemen and marcher states in Afro-Eurasian world-system synchrony. In Trinchur, G. K. (ed.), The Rise of Asia and the Transformation of the World-System, Paradigm, Boulder, CO, pp. 69-82.

Hegmon, M. (2003). Setting theoretical egos aside: Issues and theory in North American archaeology. American Antiquity 68: 213-243.

Hegmon, M. (2005). No more theory wars: A response to Moss. American Antiquity 70: 588-590.

Hollis, S. (2004). Crafting Europe's “clean slate” advantage: World-system expansion and the indigenous Mississippians of North America. American Indian Culture and Research Journal 28: 77-101.

Hollis, S. (2005). Contact, incorporation, and the North American Southeast. Journal of World-Systems Research 11: 95-130.

Hornborg, A., and Crumley, C. E. (2007). The World System and the Earth System: Global Socioenvironmental Change and Sustainability Since the Neolithic, Left Coast Books, Walnut Creek, CA.

Hornborg, A., McNeill, J., and Martínez-Alier, J. (eds.) (2007). Rethinking Environmental History: World-System History and Global Environmental Change, Rowman and Littlefield, Lanham, MD.

Jablonka, E., and Lamb, M. J. (2005). Evolution in Four Dimensions: Genetic, Epigenetic, Behavioral, and Symbolic Variation in the History of Life, MIT Press, Cambridge, MA.

Jones, T. A., and Mielants, E. (2010). Mass Migration in the World-System: Past, Present and Future, Paradigm, Boulder, CO.

Kardulias, P. N. (1990). Fur production as a specialized activity in a world system: Indians in the North American fur trade. American Indian Culture and Research Journal 14: 25-60. 
Kardulias, P. N. (1999a). Multiple levels in the Aegean Bronze Age world-system. In Kardulias, P. N. (ed.), World-Systems Theory in Practice: Leadership, Production, and Exchange, Rowman and Littlefield, Lanham, MD, pp. 179-201.

Kardulias, P. N. (1999b). Preface. In Kardulias, P. N. (ed.), World-Systems Theory in Practice: Leadership, Production, and Exchange, Rowman and Littlefield, Lanham, MD, pp. xvii-xxi.

Kardulias, P. N. (ed.) (1999c). World-Systems Theory in Practice: Leadership, Production, and Exchange, Rowman and Littlefield, Lanham, MD.

Kardulias, P. N. (1999d). Flaked stone and the role of the palaces in the Mycenaean world system. In Parkinson, W. A., and Galaty, M. (eds.), Rethinking Mycenaean Palaces: New Interpretations of an Old Idea, Institute of Archaeology, University of California, Los Angeles, pp. 61-71.

Kardulias, P. N. (2001). Negotiated peripherality: Making incorporation work for you on the margins of world-systems. Paper presented at the 100th Annual Meeting of the American Anthropological Association, Washington, DC.

Kardulias, P. N. (2007). Negotiation and incorporation on the margins of world-systems: Examples from Cyprus and North America. Journal of World-Systems Research 13: 55-82.

Kardulias, P. N., and Hall, T. D. (2007). A world-systems view of human migration past and present: Providing a general model for understanding the movement of people. Forum on Public Policy. Available at http://www.forumonpublicpolicy.com/archivesum07/kardulias.pdf.

Kardulias, P. N., and Hall, T. D. (2008). Archaeology and world-systems analysis. World Archaeology 40: $572-583$.

Kardulias, P. N., and Yerkes, R. W. (2004). World-systems theory and regional survey: The Malloura Valley survey on Cyprus. In Athanassopoulos, E., and Wandsnider, L. (eds.), Mediterranean Archaeological Landscapes: Current Issues, Museum of Archaeology and Anthropology, University of Pennsylvania, Philadelphia, pp. 143-164.

Kepecs, S., and Kohl, P. (2003). Conceptualizing macroregional interaction: World-systems theory and the archaeological record. In Smith, M. E., and Berdan, F. F. (eds.), The Postclassic Mesoamerican World, University of Utah Press, Salt Lake City, pp. 14-20.

Kohl, P. L. (1987). The use and abuse of world systems theory: The case of the pristine West Asian state. Advances in Archaeological Method and Theory 11: 1-35.

Kohl, P. L. (1989). The use and abuse of world-systems theory: The case of the "pristine" West Asian state. In Lamberg-Karlovsky, C. C. (ed.), Archaeological Thought in America, Cambridge University Press, Cambridge, pp. 218-240.

Kohl, P. L. (1992). The Transcaucasian "periphery" in the Bronze Age: A preliminary formulation. In Schortman, E., and Urban, P. (eds.), Resources, Power, and Interregional Interaction, Plenum Press, New York, pp. 117-137.

Kohl, P. L. (2002). Archaeological transformations: Crossing the pastoral/agricultural bridge. Iranica Antiqua 38: 151-190.

Kohl, P. L. (2004). Tin and interregional integration in the Bronze Age: Evidence from the Caucasus and Central Asia. Paper presented at the 105th Annual Meeting of the Archaeological Institute of America, San Francisco, CA.

Kohl, P. L. (2007). The Making of Bronze Age Eurasia, Cambridge University Press, Cambridge.

Kohl, P. L. (2008). Shared social fields: Evolutionary convergence in prehistory and contemporary practice. American Anthropologist 110: 495-506.

Kohl, P. L., and Chernykh, E. N. (2003). Different hemispheres, different worlds. In Smith, M. E., and Berdan, F. F. (eds.), The Postclassic Mesoamerican World, University of Utah Press, Salt Lake City, pp. 307-312.

Kristiansen, K. (1998a). Europe Before History, Cambridge University Press, Cambridge.

Kristiansen, K. (1998b). The emergence of the European world system in the Bronze Age: Divergence, convergence and social evolution during the first and second millennia BC in Europe. In Kristiansen, K., and Rowlands, M. (eds.), Social Transformations in Archaeology: Global and Local Perspectives, Routledge, London, pp. 287-324.

Kristiansen, K., and Larsson, T. B. (2005). The Rise of Bronze Age Society: Travels, Transmissions and Transformations, Cambridge University Press, Cambridge.

Kuecker, G. D. (2007). The perfect storm: Catastrophic collapse in the 21 st century. The International Journal of Environmental, Cultural, Economic and Social Sustainability 3: 1-10.

Kuhn, T. S. (1970). The Structure of Scientific Revolutions, 2nd ed., University of Chicago Press, Chicago.

Kuhn, T. S. (1977). Second thoughts on paradigms. In Kuhn, T. S. (ed.), The Essential Tension: Selected Studies in Scientific Traditions and Change, University of Chicago Press, Chicago, pp. 293-319. 
La Lone, D. E. (1994). An Andean world-system: Production transformations under the Inka empire. In Brumfiel, E. M. (ed.), The Economic Anthropology of the State, Monographs in Economic Anthropology No. 11, University Press of America, Lanham, MD, pp. 17-41.

La Lone, D. E. (1999). Does world-systems theory work? An ethnographer's perspective. In Kardulias, P. N. (ed.), World-Systems Theory in Practice: Leadership, Production, and Exchange, Rowman and Littlefield, Lanham, MD, pp. 297-307.

La Lone, D. E. (2000). Rise, fall, and semiperipheral development in the Andean world-system. Journal of World-Systems Research 6: 68-99.

Lenski, G. (1966). Power and Privilege: A Theory of Social Stratification, McGraw-Hill, New York.

Lenski, G. (1976). History and social change. American Journal of Sociology 82: 548-564.

Lenski, G. (2005). Ecological-Evolutionary Theory: Principles and Applications, Paradigm, Boulder, CO.

Lesser, A. (1985 [1961]). Social fields and the evolution of society. In Mintz, S. (ed.), History, Evolution, and the Concept of Culture: Selected Papers by Alexander Lesser, Cambridge University Press, Cambridge, pp. 92-99.

Love, J., Alvarez, A., Inoue, H., Lawrence, K., Courtney, E., Elias, E., Roberts, T., Genova, J., Autelli, V., Liyanage, S., Hopps J., and Chase-Dunn, C. (2010). Semiperipheral development and empire upsweeps since the Bronze Age. Paper presented at International Studies Association, New Orleans, LA [IROWS Working Paper \#56].

Marcus, J. (1993). Ancient Maya political organization. In Sabloff, J. A., and Henderson, J. S. (eds.), Lowland Maya Civilization in the Eighth Century A.D., Dumbarton Oaks, Washington, DC, pp. 111-172.

Marcus, J. (2008). The archaeological evidence for social evolution. Annual Review of Anthropology 37: 251-266.

McAnany, P. S., and Yoffee, N. (eds.) (2010). Questioning Collapse: Human Resilience, Ecological Vulnerability, and the Aftermath of Empire, Cambridge University Press, Cambridge.

McGuire, R. H., and Villalpando, M. E. (1989). Prehistory and the making of history in Sonora. In Thomas, D. H. (ed.), Columbian Consequences, Volume 1: Archaeological and Historical Perspectives on the Spanish Borderlands, Smithsonian Institution Press, Washington, DC, pp. 159-177.

McNeill, J. R., and McNeill, W. H. (2003). The Human Web, Norton, New York.

McNeill, W. H. (1963). The Rise of the West: A History of the Human Community, University of Chicago Press, Chicago.

McNeill, W. H. (1964). Europe's Steppe Frontier, 1500-1800, University of Chicago Press, Chicago.

McNeill, W. H. (1995). The Rise of the West after twenty-five years. In Sanderson, S. K. (ed.), Civilizations and World-Systems: Two Approaches to the Study of World-Historical Change, AltaMira Press, Walnut Creek, CA, pp. 289-306.

McNeill, W. H. (2000). Information and transportation nets in world history. In Denemark, R., Friedman, J., Gills, B., and Modelski, G. (eds.), World System History: The Social Science of Long-Term Change, Routledge, London, pp. 201-215.

Modelski, G., and Thompson, W. R. (1999). Evolutionary pulse of the world system: Hinterland incursions and migrations, 4000 B.C. to A.D. 1500. In Kardulias, P. N. (ed.), World-Systems Theory in Practice: Leadership, Production, and Exchange, Rowman and Littlefield, Lanham, MD, pp. 241-274.

Morris, I. (1999). Negotiated peripherality in Iron Age Greece: Accepting and resisting the East. In Kardulias, P. N. (ed.), World-Systems Theory in Practice: Leadership, Production, and Exchange, Rowman and Littlefield, Lanham, MD, pp. 63-84.

Murray, T. (ed.) (2004). The Archaeology of Contact in Settler Societies, Cambridge University Press, Cambridge.

Neitzel, J. E. (ed.) (1999). Great Towns and Regional Polities in the Prehistorical Southwest and Southeast, University of New Mexico Press, Albuquerque.

O'Brien, P. (1994). The central lowland plains: An overview. In Schlesier, K. H. (ed.), Plains Indians, A.D. 500-1500: the Archaeological Past of Historic Groups, University of Oklahoma Press, Norman, pp. 199-223.

Pailes, R. A., and Whitecotton, J. W. (1975). Greater Southwest and Mesoamerican world-systems. Paper presented at the Southwestern Anthropological Association meeting, Santa Fe, NM.

Pailes, R. A., and Whitecotton, J. W. (1979). The Greater Southwest and the Mesoamerican "world" system: An exploratory model of frontier relationships. In Savage, W. W., and Thompson, S. I. 
(eds.), The Frontier: Comparative Studies, Vol. 2, University of Oklahoma Press, Norman, pp. 105-121.

Parker, B. J., and Rodseth, L. (eds.) (2005). Untaming the Frontier in Anthropology, Archaeology, and History, University of Arizona Press, Tucson.

Parkinson, W. A. (ed.) (2002a). The Archaeology of Tribal Societies, International Monographs in Prehistory, Ann Arbor, MI.

Parkinson, W. A. (2002b). Introduction: Archaeology and tribal societies. In Parkinson, W. A. (ed.), The Archaeology of Tribal Societies, International Monographs in Prehistory, Ann Arbor, MI, pp. 1-12.

Parkinson, W. A. (2002c). Integration, interaction, and tribal 'cycling': The transition to the Copper Age on the Great Hungarian Plain. In Parkinson, W. A. (ed.), The Archaeology of Tribal Societies, International Monographs in Prehistory, Ann Arbor, MI, pp. 391-348.

Parkinson, W. A. (2006). Tribal boundaries: Stylistic variability and social boundary maintenance during the transition to the Copper Age on the Great Hungarian Plain. Journal of Anthropological Archaeology 25: 33-58.

Parkinson, W. A., and Galaty, M. (2007). Secondary states in perspective: An integrated approach to state formation in the prehistoric Aegean. American Anthropologist 109: 113-129.

Parkinson, W. A., and Galaty, M. (eds.) (2010). Archaic State Interaction: The Eastern Mediterranean in the Bronze Age, School for Advanced Research Press, Santa Fe, NM.

Peregrine, P. N. (1992). Mississippian Evolution: A World-System Perspective, Prehistory Press, Madison, WI.

Peregrine, P. N., and Feinman, G. M. (eds.) (1996). Pre-Columbian World Systems, Prehistory Press, Madison, WI.

Pitts, M. (2008). Globalizing the local in Roman Britain: An anthropological approach to social change. Journal of Anthropological Archaeology 27: 493-506.

Pollard, H. P. (2003). West Mexico beyond the Tarascan frontier. In Smith, M. E., and Berdan, F. F. (eds.), The Postclassic Mesoamerican World, University of Utah Press, Salt Lake City, pp. 55-57.

Rowlands, M. (1998). Centre and periphery: A review of a concept. In Kristiansen, K., and Rowlands, M. (eds.), Social Transformations in Archaeology: Global and Local Perspectives, Routledge, London, pp. 219-242.

Sabloff, J. A. (1990). The New Archaeology and the Ancient Maya, Freeman, New York.

Sahlins, M. D. (1960). Evolution: Specific and general. In Sahlins, M. D., and Service, E. (eds.), Evolution and Culture, University of Michigan Press, Ann Arbor, pp. 12-44.

Sahlins, M. D., and Service, E. R. (1960). Evolution and Culture, University of Michigan Press, Ann Arbor.

Sanderson, S. K. (ed.) (1995). Civilizations and World-Systems: Two Approaches to the Study of WorldHistorical Change, AltaMira Press, Walnut Creek, CA.

Sanderson, S. K. (1999a). Social Transformations: A General Theory of Historical Development, expanded ed., Rowman and Littlefield, Lanham, MD.

Sanderson, S. K. (1999b). Macrosociology: An Introduction to Human Societies, 4th ed., Longman, New York.

Sanderson, S. K. (2001). The Evolution of Human Sociality: A Darwinian Conflict Perspective, Rowman and Littlefield, Lanham, MD.

Sanderson, S. K., and Alderson, A. S. (2005). World Societies: The Evolution of Human Social Life, Pearson, Allyn and Bacon, Boston, MA.

Santley, R. S., and Alexander, R. T. (1992). The political economy of core-periphery systems. In Schortman, E. M., and Urban, P. A. (eds.), Resources, Power, and Interregional Interaction, Plenum, New York, pp. 23-49.

Schneider, J. (1977). Was there a pre-capitalist world-system? Peasant Studies 6: 20-29.

Schortman, E. M., and Urban, P. A. (1987). Modeling interregional interaction in prehistory. Advances in Archaeological Method and Theory 11: 37-95.

Schortman, E. M., and Urban, P. A. (eds.) (1992). Resources, Power, and Interregional Interaction, Plenum, New York.

Schortman, E. M., and Urban, P. A. (1994). Living on the edge: Core/periphery relations in ancient southeastern Mesoamerica. Current Anthropology 35: 401-430.

Schortman, E. M., and Urban, P. A. (1999). Thoughts on the periphery: The ideological consequences of core/periphery relations. In Kardulias, P. N. (ed.), World-Systems Theory in Practice: Leadership, Production, and Exchange, Rowman and Littlefield, Lanham, MD, pp. 125-152.

Shannon, T. R. (1989). An Introduction to the World-System Perspective, Westview Press, Boulder, CO. 
Shannon, T. R. (1996). An Introduction to the World-System Perspective, 2d ed., Westview Press, Boulder, $\mathrm{CO}$.

Sherratt, A. (1993). What would a Bronze-Age world system look like? Relations between temperate Europe and the Mediterranean in later prehistory. Journal of European Archaeology 1: 1-57.

Sherratt, A. (1997). Economy and Society in Prehistoric Europe, Edinburgh University Press, Edinburgh.

Sherratt, A. (2003). The horse and the wheel: The dialectics of change in the circum-Pontic region and adjacent areas, 4500-1500 BC. In Levine, M., Renfrew, C., and Boyle, K. (eds.), Prehistoric Steppe Adaptation and the Horse, McDonald Institute Monographs, Oxbow Books, Cambridge, pp. 233-252.

Sherratt, A. (2006). The Trans-Eurasian exchange: The prehistory of Chinese relations with the west. In Mair, V. H. (ed.), Contact and Exchange in the Ancient World, University of Hawai'i Press, Honolulu, pp. 30-61.

Sherratt, A., and Sherratt, S. (1991). From luxuries to commodities: The nature of Mediterranean Bronze Age trading systems. In Gale, N. H. (ed.), Bronze Age Trade in the Mediterranean, Paul Astroms Forlag, Jonsered, pp. 351-386.

Sherratt, A., and Sherratt, S. (1993). The growth of the Mediterranean economy in the early first millennium BC. World Archaeology 24: 361-378.

Sherratt, S. (2001). Potemkin palaces and route-based economies. In Voutsaki, S., and Killen, J. (eds.), Economy and Politics in the Mycenaean Palace States, Cambridge Philological Society, Cambridge, pp. 214-238.

Sherratt, S. (2003). The Mediterranean economy: 'Globalization' at the end of the second millennium BCE. In Dever, W. G., and Gitin, S. (eds.), Symbiosis, Symbolism, and the Power of the Past: Canaan, Ancient Israel, and Their Neighbors from the Late Bronze Age through Roman Palaestina, Eisenbrauns, Winona Lake, IN, pp. 37-62.

Sklair, L. (2006). Competing conceptions of globalization. In Chase-Dunn, C., and Babones, S. (eds.), Global Social Change: Comparative and Historical Perspectives, Johns Hopkins University Press, Baltimore, MD, pp. 59-78.

Smith, A. T., and Rubinson, K. S. (eds.) (2003). Archaeology in the Borderlands: Investigations in Caucasia and Beyond, Cotsen Institute of Archaeology, University of California, Los Angeles.

Smith, D. A., and Timberlake, M. (2001). World city networks and hierarchies, 1977-(1997): An empirical analysis of global air travel links. American Behavioral Scientist 44: 1656-1679.

Smith, M. E. (2003a). Key commodities. In Smith, M. E., and Berdan, F. F. (eds.), The Postclassic Mesoamerican World, University of Utah Press, Salt Lake City, pp. 117-125.

Smith, M. E. (2003b). Information networks in Postclassic Mesoamerica. In Smith, M. E., and Berdan, F. F. (eds.), The Postclassic Mesoamerican World, University of Utah Press, Salt Lake City, pp. 181-185.

Smith, M. (2005). Networks, territories, and the cartography of ancient states. Annals of the Association of American Geographers 95: 832-849.

Smith, M. E., and Berdan, F. F. (eds.) (2003a). The Postclassic Mesoamerican World, University of Utah Press, Salt Lake City.

Smith, M. E., and Berdan, F. F. (2003b). Postclassic Mesoamerica. In Smith, M. E., and Berdan, F. F. (eds.), The Postclassic Mesoamerican World, University of Utah Press, Salt Lake City, pp. 3-13.

Smith, M. E., and Berdan, F. F. (2003c). Spatial structure of the Mesoamerican world-system. In Smith, M. E., and Berdan, F. F. (eds.), The Postclassic Mesoamerican World, University of Utah Press, Salt Lake City, pp. 21-31.

Stark, M. T. (1998). The Archaeology of Social Boundaries, Smithsonian Institution Press, Washington, DC.

Stein, G. (1999). Rethinking World-Systems. Diasporas, Colonies, and Interaction in Uruk Mesopotamia, University of Arizona Press, Tucson.

Stein, G. (2002). From passive periphery to active agents: Emerging perspectives in the archaeology of interregional interaction. American Anthropologist 104: 903-916.

Stein, G. (ed.) (2005). The Archaeology of Colonial Encounters: Comparative Perspectives, School of American Research Press, Santa Fe, NM.

Tainter, J. A. (1988). The Collapse of Complex Societies, Cambridge University Press, Cambridge.

Tainter, J. A. (2007). Scale and dependency in world-systems: Local societies in convergent evolution. In Hornborg, A., McNeill, J., and Martínez-Alier, J. (eds.), Rethinking Environmental History: WorldSystem History and Global Environmental Change, Rowman and Littlefield, Lanham, MD, pp. 361-377. 
Tainter, J. A., and Tainter, B. B. (eds.) (1996). Evolving Complexity and Environmental Risk in the Prehistoric Southwest, Santa Fe Institute, Santa Fe, NM.

Teggart, F. J. (1939). Rome and China: A Study of Correlations in Historical Events, University of California Press, Berkeley.

Thompson, W. R. (1983). Introduction: World system analysis with and without the hyphen. In Thompson, W. R. (ed.), Contending Approaches to World System Analysis, Sage, Beverly Hills, CA, pp. 7-24.

Thompson, W. R. (2000). Comparing approaches to the social science history of the world system. In Denemark, R., Friedman, J., Gills, B., and Modelski, G. (eds.), World System History: The Social Science of Long-Term Change, Routledge, London, pp. 287-298.

Tsetskhladze, G. R. (2003). The culture of ancient Georgia in the first millennium B.C. and greater Anatolia: Diffusion or migration? In Smith, A. T., and Rubinson, K. S. (eds.), Archaeology in the Borderlands: Investigations in Caucasia and Beyond, Cotsen Institute of Archaeology, University of California, Los Angeles, pp. 229-245.

Tsetskhladze, G. R. (ed.) (2006). Greek Colonisation: An Account of Greek Colonies and Other Settlements Overseas, Brill, Leiden.

Turchin, P. (2003). Historical Dynamics: Why States Rise and Fall, Princeton University Press, Princeton, NJ.

Turchin, P. (2009). A theory for formation of large empires. Journal of Global History 4: 191-217.

Turchin, P., and Hall, T. D. (2003). Spatial synchrony among and within world-systems: Insights from theoretical ecology. Journal of World-Systems Research 9: 37-64.

Turchin, P., and Nefedov, S. A. (2009). Secular Waves, Princeton University Press, Princeton, NJ.

Van Dyke, R. M. (2007). The Chaco Experience: Landscape and Ideology at the Center Place, School for Advanced Research Press, Santa Fe, NM.

Villalpando, M. E. (ed.) (2002). Boundaries and Territories: Prehistory of the U.S. Southwest and Northern Mexico, Anthropological Research Papers No. 54, Arizona State University, Tempe.

Wallace, W. (1971). The Logic of Science in Sociology, Aldine, Chicago.

Wallerstein, I. (1974). The Modern World-System: Capitalist Agriculture and the Origins of European World-Economy in the Sixteenth Century, Academic Press, New York.

Wallerstein, I. (1983). An agenda for world-systems analysis. In Thompson, W. R. (ed.), Contending Approaches to World System Analysis, Sage, Beverly Hills, CA, pp. 299-308.

Wallerstein, I. (1993). World system vs. world-systems. In Frank, A. G., and Gills, B. K. (eds.), The World System: Five Hundred Years or Five Thousand? Routledge, London, pp. 291-296.

Wallerstein, I. (1995). Hold the tiller firm: On method and the unit of analysis. In Sanderson, S. K. (ed.), Civilizations and World-Systems: Two Approaches to the Study of World-Historical Change, AltaMira Press, Walnut Creek, CA, pp. 225-233.

Wallerstein, I. (2004). World-Systems Analysis: An Introduction, Duke University Press, Durham, NC.

Ward, K. (ed.) (1990). Women Workers and Global Restructuring, ILR Press, Ithaca, NY.

Ward, K. (1993). Reconceptualizing world-system theory to include women. In England, P. (ed.), Theory on Gender/Feminism on Theory, Aldine, New York, pp. 43-68.

Watkins, J. (2003). Beyond the margin: American Indians, First Nations, and archaeology in North America. American Antiquity 68: 273-285.

Wells, P. S. (1999a). The Barbarians Speak: How the Conquered Peoples Shaped Roman Europe, Princeton University Press, Princeton, NJ.

Wells, P. S. (1999b). Production within and beyond imperial boundaries: Goods, exchange, and power in Roman Europe. In Kardulias, P. N. (ed.), World-Systems Theory in Practice: Leadership, Production, and Exchange, Rowman and Littlefield, Lanham, MD, pp. 85-102.

White, D. R. (2003a). Networks and complexity: Converging streams of research. Complexity 8: 14.

White, D. R. (ed.) (2003b). Networks and Complexity, special issue of Complexity 8: 3-95.

White, D. R., and Johansen, U. C. (2005). Network Analysis and Ethnographic Problems: Process Models of a Turkish Nomad Clan, Lexington Books, Lanham, MD.

White, R. (1991). The Middle Ground, Cambridge University Press, Cambridge.

Wilcox, D. R., Wiegand, P. C., Wood, S., and Howard, J. B. (2008). Ancient cultural interplay of the American Southwest and the Mexican Northwest. Journal of the Southwest 50: 103-206.

Wilkinson, D. (2000). Civilizations, world systems and hegemonies. In Denemark, R., Friedman, J., Gills, B., and Modelski, G. (eds.), World System History: The Social Science of Long-Term Change, Routledge, London, pp. 54-84.

Wolf, E. R. (1982). Europe and the People Without History, University of California Press, Berkeley. 


\section{Supplemental bibliography: Online resources}

Journal of World-Systems Research: http://jwsr.ucr.edu/index.php Institute for Research on World-Systems: http://irows.ucr.edu/

World-Systems Archive: http://wsarch.ucr.edu/

\section{Bibliography of recent literature}

Alcock, S. E., D’Altroy, T. E., Morrison, K. D., and Sinopoli, C. M. (eds.) (2001). Empires: Perspectives from Archaeology and History, Cambridge University Press, Cambridge.

Algaze, G. (2001). Initial social complexity in southwestern Asia: The Mesopotamian advantage. Current Anthropology 42: 199-233.

Anon. (1998). Archaeology: Transitions in prehistory. Science 282: 1441-1458.

Batten, B. L. (2003). To the Ends of Japan: Premodern Frontiers, Boundaries, and Interactions, University of Hawaii Press, Honolulu.

Bentley, J. H., and Ziegler, H. (2006). Traditions and Encounters: A Global Perspective on the Past, 3rd ed., McGraw-Hill, New York.

Bentley, J. H., Bridenthal, R., and Yang, A. A. (eds.) (2005). Interactions: Transregional Perspectives on World History, University of Hawaii Press, Honolulu.

Blackhawk, N. (2006). Violence over the Land: Indians and Empires in the Early American West, Harvard University Press, Cambridge, MA.

Blanton, R. E., Fargher, L. F., and Heredia Espinoza, V. Y. (2005). The Mesoamerican world of goods and its transformations. In Blanton, R. E. (ed.), Settlement, Subsistence and Social Complexity: Essays Honoring the Legacy of Jeffrey Parsons, Cotsen Institute of Archaeology, University of California, Los Angeles, pp. 260-294.

Boatca, M. (2003). From Neoevolutionism to World-Systems Analysis: The Romanian Theory of "Forms without Substance" in Light of Modern Debates on Social Change, Leske and Budrich, Opladen, Germany.

Brumfiel, E. M., and Earle, T. K. (eds.) (1987). Specialization, Exchange, and Complex Societies, Cambridge University Press, Cambridge.

Burch, E. S., Jr. (2005). Alliance and Conflict: A World System of the Iñpiaq Eskimos, University of Nebraska Press, Lincoln.

Carmack, R. M., and González, S. S. (2006). A world-systems perspective on the archaeology and ethnohistory of the Mesoamerican/lower Central American border. Ancient Mesoamerica 17: 219-229.

Chase-Dunn, C., and Hall, T. D. (1998). World-systems in North America: Networks, rise and fall and pulsations of trade in stateless systems. American Indian Culture and Research Journal 22: 23-72.

Chase-Dunn, C., and Hall, T. D. (2008). East and west in world-systems evolution. Paper presented at Andre Gunder Frank's Legacy of Critical Social Science, University of Pittsburgh ( http://irows.ucr.edu/papers/irows42/irows42.htm).

Chase-Dunn, C., Inoue, H., Alvarez, A., Lawrence, K., and Love, J. (2009). Synchronous east-west urban and empire upsweeps? Paper presented at the Annual Meeting of the Social Science History Association, Long Beach, CA (http://irows.ucr.edu/papers/irows53/irows53.htm).

Chew, S. C. (2006). Dark ages, ecological crises phases and system transition. In Jorgenson, A., and Kick, E. (eds.), Globalization and the Environment, Brill, Leiden, pp. 253-290.

Crawford, H. (ed.) (2007). Regime Change in the Ancient Near East and Egypt: From Sargon of Agade to Saddam Hussein, Oxford University Press, Oxford.

Dearing, J. A. (2006). Climate-human-environment interactions: Resolving our past. Climate of the Past 2: $187-203$.

Feinman, G. M., and Marcus, J. (eds.) (1998). Archaic States, School of American Research Press, Santa Fe, NM.

Feinman, G. M., and Nicholas, L. M. (eds.) (2004). Archaeological Perspectives on Political Economies, University of Utah Press, Salt Lake City.

Frank, A. G. (1992). The Centrality of Central Asia, VU University Press, Amsterdam. 
Galaty, M. (2002). Modeling the formation and evolution of an Illyrian tribal system: Ethnographic and archaeological analogs. In Parkinson, W. A. (ed.), The Archaeology of Tribal Societies, International Monographs in Prehistory, Ann Arbor, MI, pp. 109-122.

Gills, B. K., and Thompson, W. R. (eds.) (2006). Globalization and Global History, Routledge, London.

Grattan, J. P., Gilbertson, D. D., and Hunt, C. O. (2007). The local and global dimensions of metalliferous pollution derived from a reconstruction of an eight thousand year record of copper smelting and mining at a desert-mountain frontier in southern Jordan. Journal of Archaeological Science 34: $83-110$.

Gregory, R. J. (2004). What is world systems all about? An introduction for human ecologists. Journal of Human Ecology 16: 193-196.

Hiebert, F. T., and Dyson, R. H., Jr. (2002). Prehistoric Nishapur and the frontier between Central Asia and Iran. Iranica Antiqua 37: 113-149.

Hudson, B. (2008). Restoration and reconstruction of monuments at Bagan (Pagan), Myanmar (Burma), 1995-2008. World Archaeology 40: 553-571.

Jones-Bley, K., and Zdanovich, D. G. (eds.) (2002). Complex Societies of Central Eurasia from the 3rd to the 1st Millennium BC: Regional Specifics in Light of Global Models, Vols. 1 and 2, Institute for the Study of Man, Washington, DC.

Lanata, J. L., Martino, L., Osella, A., and Garcia-Herbst, A. (2008). Demographic conditions necessary to colonize new spaces: The case for early human dispersal in the Americas. World Archaeology 40: 520-537.

Lindert, P. H., Milanovic, B., and Williamson, J. G. (2007). Measuring ancient inequality. MPRA Paper No. 5388, posted 07 November (http://mpra.ub.uni-muenchen.de/5388/).

Mair, V. H. (ed.) (1998). The Bronze Age and Early Iron Age Peoples of Eastern Central Asia, 2 Vols., Institute for the Study of Man, Washington, DC.

Mair, V. H. (ed.) (2006). Contact and Exchange in the Ancient World, University of Hawai'i Press, Honolulu.

Manning, P. (1996). The problem of interactions in world history. American Historical Review 101: $771-782$.

Manning, J. G., and Morris, I. (2005). The Ancient Economy: Evidence and Models, Stanford University Press, Stanford, CA.

Meyer, W. B. (2000). Appendix A: Climate and migration. In Bell-Failkoff, A. (ed.), The Role of Migration in the History of the Eurasian Steppe: Sedentary Civilization vs. "Barbarian" and Nomad, St. Martin's Press, New York, pp. 287-294.

Milanovic, B., Lindert, P., and Williamson, J. (2007). Measuring ancient inequality. National Bureau of Economic Research, MPRA Paper No. 5388, posted 07 November 2007 (http://mpra.ub.uni-muen chen.de/5388/).

Paris, E. H. (2008). Metallurgy, Mayapan and the postclassic Mesoamerican world system. Ancient Mesoamerica 19: 43-66.

Parker, B. J. (2002). At the edge of empire: Conceptualizing Assyria's Anatolian frontier ca. 700 BC. Journal of Anthropological Archaeology 21: 371-395.

Peregrine, P. N. (2000). Archaeology and world-systems theory. In Hall, T. D. (ed.), A World-Systems Reader: New Perspectives on Gender, Urbanism, Cultures, Indigenous Peoples, and Ecology, Rowman and Littlefield, Lanham, MD, pp. 59-68.

Peregrine, P. N. (2006). Synchrony in the New World: An example of archaeoethnology. Cross-Cultural Research 40: 6-17.

Rice, P. M., and Rice, D. S. (2005). The final frontier of the Maya: Central Peten, Guatemala, AD. 14501700. In Parker, B. J., and Rodseth, L. (eds.), Untaming the Frontier in Anthropology, Archaeology, and History, University of Arizona Press, Tucson, pp. 147-173.

Rothman, M. S. (ed.) (2001). Uruk Mesopotamia and Its Neighbors: Cross-Cultural Interaction in the Era of State Formation, School of American Research Press, Santa Fe, NM.

Schon, R., and Galaty, M. L. (2006). Diachronic frontiers: Landscape archaeology in highland Albania. Journal of World-Systems Research 12: 231-262.

Schweizer, T., and White, D. R. (eds.) (1998). Kinship, Networks, and Exchange, Cambridge University Press, Cambridge.

Sherratt, A. (1996). Plate tectonics and imaginary prehistories: Structure and contingency in agricultural origins. In Harris, D. R. (ed.), The Origin and Spread of Agriculture and Pastoralism in Eurasia, UCI Press, London, pp. 130-140. 
Sing, S. J. (2003). In the Sea of Influence: A World System Perspective of the Nicobar Islands, Lund University Press, Lund, Sweden.

Skinner, G. W., Henderson, M., and Yuan, J. (2000). China's fertility transition through regional space: Using GIS and census data for a spatial analysis of historical demography. Social Science History 24: 613-652.

Sklair, L. (2002). Globalization: Capitalism and Its Alternatives, 3rd ed., Oxford University Press, Oxford.

Smith, M. E. (2005). City size in Late Postclassic Mesoamerica. Journal of Urban History 31: 403-434.

Smith, M. E. (2006). How do archaeologists compare early states? Reviews in Anthropology 35: 5-35.

Smith, M. E. (2010, in press). Sprawl, squatters, and sustainable cities: Can archaeological data shed light on modern urban issues? Cambridge Archaeological Journal.

Smith, M. E., and Montiel, L. (2001). The archaeological study of empires and imperialism in prehispanic central Mexico. Journal of Anthropological Archaeology 20: 245-284.

Smith, M. E., and Schreiber, K. J. (2005). New World states and empires: Economic and social organization. Journal of Archaeological Research 13: 189-229.

Smith, M. E., and Schreiber, K. J. (2006). New World states and empires: Politics, religion, and urbanism. Journal of Archaeological Research 14: 1-52.

Smith, M. E., and Schreiber, K. J. (2004). The archaeology of ancient state economies. Annual Review of Anthropology 33: 73-102.

Stark, M. T. (ed.) (2006). Archaeology of Asia, Blackwell, Malden, MA.

Stein, G. J. (2001). Understanding ancient state societies in the Old World. In Feinman, G. M., and Price, T. D. (eds.), Archaeology at the Millennium: A Sourcebook, Plenum, New York, pp. 353-379.

St.-Hilaire, A. (2000). Global incorporation and cultural survival: The Surinamese Maroons at the margins of the world-system. Journal of World-Systems Research 6: 102-132.

Taagepera, R., and Kaskla, E. (2001). The city-country rule: An extension of the rank-size rule. Journal of World-Systems Research 7: 157-173.

Tainter, J. (2000). Problem solving: Complexity, history, and sustainability. Population and Environment: A Journal of Interdisciplinary Studies 22: 3-41.

Tainter, J. (2006). Archaeology of overshoot and collapse. Annual Review of Anthropology 35: 59-74.

Taylor, P. J. (2001). New political geographies 'twixt places and flows'. Globalization and World Cities Study Group, Research Bulletin 52 (www.Lboro.ac.uk/gawc/rb/rb52.html).

Teyssandier, N. (2008). Revolution or evolution: The emergence of the Upper Paleolithic in Europe. World Archaeology 40: 493-519.

Turchin, P., Adams, J. M., and Hall, T. D. (2006). East-west orientation of historical empires and modern states. Journal of World-Systems Research 12: 218-229.

White, D. R., and Houseman, M. (2003). The navigability of strong ties: Small worlds, tie strength, and network topology self-organization in strong-tie small worlds. Complexity 8: 72-81.

Wilkinson, D. (2003). Civilizations as networks: Trade, war, diplomacy, and command-control: Statesystems bonded by influence, alliance, and war relations. Complexity 8: 82-86.

Wright, R. P. (2002). Revisiting interaction spheres: Social boundaries and technologies on inner and outermost frontiers. Iranica Antiqua 37: 403-417.

Yang, B. (2004). Horses, silver, and cowries: Yunnan in global perspective. Journal of World History 15: 281-322.

Yang, B. (2009). Between Winds and Clouds: The Making of Yunnan Second Century BCE to Twentieth Century CE, Columbia University Press, New York. 